\title{
Solar photoelectro-Fenton flow plant modeling for the degradation of the antibiotic erythromycin in sulfate medium
}

\author{
Tzayam Pérez ${ }^{\mathrm{a}, 1}$, Ignasi Sirés ${ }^{\mathrm{b}, 1}$, Enric Brillas ${ }^{\mathrm{b}, 1}$, José L. Nava ${ }^{\mathrm{c}, *, 1}$ \\ ${ }^{a}$ Universidad de Guanajuato, Departamento de Ingeniería Química, Norial Alta S/N, 36050 Guanajuato, Guanajuato, Mexico \\ b Laboratori d'Electroquímica dels Materials i Medi Ambient, Departament de Química Física, Facultad de Química, Universitat de Barcelona, Martí i Franquès 1-11, 08028 \\ Barcelona, Spain \\ ${ }^{\mathrm{c}}$ Universidad de Guanajuato, Departamento de Geomática e Hidráulica, División de Ingenierías, Av. Juárez 77, Col. Centro, C.P. 36000, Mexico
}

\section{A R T I C L E I N F O}

\section{Article history:}

Received 18 October 2016

Received in revised form 20 December 2016

Accepted 9 January 2017

Available online xxx

\section{Keywords:}

CPC photoreactor

Filter-press reactor

Pharmaceuticals

Solar photoelectro-Fenton

Water treatment

\section{A B S T R A C T}

A solar photoelectro-Fenton (SPEF) plant containing a filter-press FM01-LC flow reactor in series with a compound parabolic collector (CPC) as photoreactor, operating in batch recirculation mode, was simulated using a parametric model. The degradation of $10 \mathrm{dm}^{3}$ of solutions of the heterocyclic antibiotic erythromycin (ERY) in $0.050 \mathrm{~mol} \mathrm{dm}^{-3} \mathrm{Na}_{2} \mathrm{SO}_{4}$ at $\mathrm{pH} 3.0$ was used for validation. The filter-press reactor contained a platinized titanium plate anode and a graphite-felt cathode that produced $\mathrm{H}_{2} \mathrm{O}_{2}$ from the reduction of dissolved oxygen $\left(0.24 \mathrm{mmol} \mathrm{dm}{ }^{-3}\right)$. Trials were performed under potentiostatic and galvanostatic conditions with predominance of $\mathrm{H}_{2} \mathrm{O}_{2}$ production, minimizing $\mathrm{H}_{2}$ evolution reaction. The effect of initial catalyst $\left(\mathrm{Fe}^{2+}\right)$ concentration, current density $(j)$, initial antibiotic concentration as dissolved organic carbon (DOC) and volumetric flow rate on the ERY mineralization was studied. Good agreement between simulations and experimental DOC decays was obtained. Mineralization current efficiencies and specific energy consumptions were also determined. The best performance under galvanostatic conditions was found for $0.225 \mathrm{mmol} \mathrm{dm}^{-3} \mathrm{ERY}\left(100 \mathrm{mg} \mathrm{dm}^{-3}\right.$ DOC), $0.50 \mathrm{mmol} \mathrm{dm}{ }^{-3} \mathrm{Fe}^{2+}$, volumetric flow rate of $3.0 \mathrm{dm}^{3} \mathrm{~min}^{-1}$ and $j_{\text {cath }}=0.16 \mathrm{~mA} \mathrm{~cm}^{-2}$, reaching $69 \%$ mineralization with current efficiency of $75 \%$ and specific energy consumption of $0.059 \mathrm{kWh}\left(\mathrm{g}\right.$ DOC) ${ }^{-1}$. Six organic by-products were identified by gas chromatography-mass spectrometry, whereas final short-chain carboxylic acids like formic and oxalic acid were detected by ion-exclusion high-performance liquid chromatography. The initial $\mathrm{N}$ atom of ERY was predominantly converted into $\mathrm{NO}_{3}^{-}$ion, although $\mathrm{NH}_{4}^{+}$ion was formed as well.

(C) 2016 Published by Elsevier Ltd.

\section{Introduction}

Erythromycin (ERY, $\mathrm{C}_{37} \mathrm{H}_{67} \mathrm{NO}_{13}, M=733.93 \mathrm{~g} \mathrm{~mol}^{-1}$ ) is one of the most widely used macrolide antibiotics, being produced by the actinomycete Saccharopolyspora erythraea. ERY has a macrocyclic lactone ring structure (see formula in Fig. 1) that prevents bacterial growth by binding to the $23 \mathrm{~S}$ ribosomal RNA, inhibiting protein synthesis. Macrolide antibiotics have relatively broad-spectrum effects on Gram-positive and Gram-negative bacteria [1,2]. ERY is widely used not only in humans, but also in food-producing animals to control bacterial diseases and promote animal growth $[3,4]$.

Water pollution by ERY arises from emission from production sites, direct disposal of drugs in households and hospitals, and excretion after drug administration to humans and animals [5-7]. The portion of an ERY dose in humans excreted via urine varies from 0.02 to $20 \%$ [8], being $15 \%$ via feces [9]. This active compound may negatively affect the microbial community in the biological treatment units of wastewater treatment plants (WWTPs) [1]. Traces of ERY from ng $\mathrm{dm}^{-3}$ to $\mu \mathrm{g} \mathrm{dm}^{-3}$ have been found in WWTP effluents [10] due to

\footnotetext{
* Corresponding author.

Email addresses: t.perezsegura@ugto.mx (T. Pérez); i.sires@ub.edu (I. Sirés); brillas@ub.edu (E. Brillas); jlnm@ugto.mx, jlnavam@yahoo.com.mx (J.L. Nava) ${ }^{1}$ Active ISE member.
}

its low biodegradability, poor photodegradability under natural conditions and high solubility in water $\left(1.34 \mathrm{~g} \mathrm{dm}^{-3}\right)[11,12]$. This antibiotic has also been detected in rivers in Europe [13], USA [14] and China [15]. Wan et al. [15] found that ERY affects the growth, metabolism and photosynthesis of one species of cyanobacteria. Moreover, an inhibitory action of ERY over liver metabolic process of fishes has been reported $[16,17]$. In humans, it is harmful to the colonic microflora, similarly to other broad-spectrum antibiotics [18].

To avoid the adverse effects of ERY, potent methods have to be developed for its removal from wastewater. Poor destruction of this antibiotic has been found by photolysis under simulated solar irradiation [11], ozonation [19,20] and in anaerobic sequencing batch reactors [21]. Better performance has been obtained by using advanced oxidation processes (AOPs), which are potent chemical, photochemical, photocatalytic, electrochemical and photoelectrochemical technologies that allow the in-situ production of hydroxyl radicals ( - $\mathrm{OH})$ [22-25]. The high standard reduction potential of this radical $\left(E^{\circ}=2.80 \mathrm{~V}\right.$ vs SHE) ensures its non-selective attack over most organics, yielding $\mathrm{CO}_{2}$ in some cases. Michael-Kordatou et al. [26] reported $37 \%$ and $63 \%$ of ERY degradation by ${ }^{\circ} \mathrm{OH}$ and sulfate radicals, respectively, in secondary WWTPs with $100 \mu \mathrm{g} \mathrm{dm}^{-3}$ of the antibiotic using a UV-C-assisted AOP. Karaolia et al. [27] described that a membrane bioreactor followed by solar Fenton oxidation allowed the removal of $95 \%$ ERY from an influent with $92 \mathrm{ng} \mathrm{L}^{-1}$. 
<smiles>CCC1OC(=O)C(C)C2OC3CC(C)(OC)C(O)C(C)(O3)OC(OC(C)CC(N(C)C)C2O)C(O)C(C)C(=O)C(C)CC(C)(O)C(OC2C(O)CC(C)(O)C(C)(O)C2O)C1C</smiles>

Fig. 1. Molecular structure of erythromycin (ERY, 1).

Other AOPs like Fenton oxidation [28,29] and $\mathrm{TiO}_{2}$ photocatalysis [30] have also yielded good results. Moreover, an electrochemical AOP (EAOP) such as anodic oxidation $(\mathrm{AO})$ with a boron-doped diamond (BDD) anode led to complete removal of $77.5 \mathrm{mg} \mathrm{L}^{-1}$ of this antibiotic in $1 \mathrm{~mol} \mathrm{dm}^{-3}$ sulfate medium by employing a current density $(j)$ of $37.5 \mathrm{~mA} \mathrm{~cm}^{-2}$ [20]. However, the application of EAOPs based on Fenton's reaction chemistry like electro-Fenton (EF), photoelectro-Fenton (PEF) and solar PEF (SPEF) to wastewater containing ERY has not been reported so far.

The EF process is the most popular EAOP based on the $\mathrm{H}_{2} \mathrm{O}_{2}$ generation by cathodic reduction of $\mathrm{O}_{2}$ injected to the treated solution via reaction (1). Efficient $\mathrm{H}_{2} \mathrm{O}_{2}$ production is obtained at carbonaceous cathodes including activated carbon fiber [31], graphite felt [32], carbon felt [33-36] and carbon-polytetrafluoroethylene (PTFE) gas $\left(\mathrm{O}_{2}\right.$ or air) diffusion [37-42]. The oxidation power of electrogenerated $\mathrm{H}_{2} \mathrm{O}_{2}$ is upgraded by the addition of a small quantity of $\mathrm{Fe}^{2+}$ to produce $\mathrm{Fe}^{3+}$ and ${ }^{\bullet} \mathrm{OH}$ in the bulk from the well-known Fenton's reaction (2) at optimum $\mathrm{pH}$ near 3 . The method is advantageous compared to classical Fenton because of the propagation of this reaction by reduction of $\mathrm{Fe}^{3+}$ to $\mathrm{Fe}^{2+}$ at the cathode from reaction (3) [22-25]:

$$
\begin{aligned}
& \mathrm{O}_{2(\mathrm{~g})}+2 \mathrm{H}^{+}+2 \mathrm{e}^{-} \rightarrow \mathrm{H}_{2} \mathrm{O}_{2} \\
& \mathrm{H}_{2} \mathrm{O}_{2}+\mathrm{Fe}^{2+} \rightarrow \mathrm{Fe}^{3+}+\cdot \mathrm{OH}+\mathrm{OH}^{-} \\
& \mathrm{Fe}^{3+}+\mathrm{e}^{-} \rightarrow \mathrm{Fe}^{2+}
\end{aligned}
$$

In an undivided cell, physisorbed $\mathrm{M}\left({ }^{\bullet} \mathrm{OH}\right)$ is also formed at the surface of a large $\mathrm{O}_{2}$-overpotential anode $\mathrm{M}$ from water oxidation by reaction (4) at high applied current. Truly free (i.e., loosely adsorbed to $\mathrm{M}$ ) heterogeneous radicals can only be formed at non-active anodes like $\mathrm{PbO}_{2}$ and BDD. Organics are then attacked by both, $\mathrm{M}\left({ }^{\bullet} \mathrm{OH}\right)$ and - $\mathrm{OH}$ radicals, although the latter is more effective to remove aromatic products [22-25].

$$
\mathrm{M}+\mathrm{H}_{2} \mathrm{O} \rightarrow \mathrm{M}(\cdot \mathrm{OH})+\mathrm{H}^{+}+\mathrm{e}^{-}
$$

The degradation of organics can be accelerated by irradiating the solution with UVA light from either a commercial lamp in PEF or sunlight in SPEF $[43,44]$. This radiation causes the photolysis of $\mathrm{Fe}(\mathrm{OH})^{2+}$ species, the pre-eminent $\mathrm{Fe}(\mathrm{III})$ species at $\mathrm{pH}$ near 3 , to regenerate $\mathrm{Fe}^{2+}$ enhancing the ${ }^{\bullet} \mathrm{OH}$ production via reaction (5), as well as the photolysis of many intermediates including the photodecarboxylation of $\mathrm{Fe}(\mathrm{III})$ complexes with final carboxylic acids from reaction (6) [22-25]:

$$
\begin{aligned}
& \mathrm{Fe}(\mathrm{OH})^{2+}+h v \rightarrow \mathrm{Fe}^{2+}+\cdot \mathrm{OH} \\
& \mathrm{Fe}(\mathrm{OOCR})^{2+}+h v \rightarrow \mathrm{Fe}^{2+}+\mathrm{CO}_{2}+\mathrm{R}^{\bullet}
\end{aligned}
$$

In previous work, we have shown some of the interesting features of the SPEF approach to efficiently degrade pharmaceuticals $[38,41,42]$. Now, our interest is to demonstrate its viability to destroy pollutants with different chemical structures, thus pointing toward the future industrial scale-up for treating real wastewater discharged by pharmaceutical companies. For this, the SPEF process needs to be modeled from an electrochemical engineering point of view, which has not been addressed yet.

The experimental characterization and modeling of the reaction environment in electrochemical flow reactors is mandatory to control homogeneous fluid flow [45], mass transport to and from electrode surface [46] and current and potential distribution [46,47], aiming to prevent parasitic reactions that impact negatively on the current efficiency and energy consumption [45]. Furthermore, the modeling of EAOPs is also needed to enhance the reaction kinetics. The numerical simulation can also be a powerful tool to devise new reactors for EAOPs, thus contributing to a smarter scale-up.

There are several chemical engineering studies dedicated to modeling the degradation of persistent organic pollutants upon use of photocatalytic AOPs [48-51]. For example, Wols et al. [50] used computational fluid dynamics (CFD) to develop a kinetic model for the removal of a mixture of pharmaceuticals, including ERY. However, the SPEF process involving the coupling of an electrochemical reactor and a solar photoreactor has not been modeled yet.

This paper presents a theoretical model for the SPEF mineralization of ERY solutions in $0.050 \mathrm{~mol} \mathrm{dm}{ }^{-3} \mathrm{Na}_{2} \mathrm{SO}_{4}$ at $\mathrm{pH} \mathrm{3}$, operating in batch recirculation mode. A global parametric model to simulate the transient mineralization rate of ERY (including the formed by-products and intermediates), in terms of total dissolved organic carbon (DOC) decay, was conceived. This model takes into account the transport phenomena in the well-engineered filter-press FM01-LC electrochemical flow reactor $[45,52]$, coupled in series with a CPC photoreactor, with a reservoir containing $10 \mathrm{dm}^{3}$ of the antibiotic solution. The equations were numerically solved using the finite element method and theoretical DOC concentration trends were validated with experimental data. The FM01-LC reactor was equipped with a platinized Ti plate anode and a graphite-felt (GF) cathode where the dissolved oxygen $\left(0.24 \mathrm{mmol} \mathrm{dm}{ }^{-3}\right)$ was reduced to $\mathrm{H}_{2} \mathrm{O}_{2}$ via reaction (1) [53]. The effect of $\mathrm{Fe}^{2+}$ concentration, applied $j$, ERY concentration and volumetric flow rate on the antibiotic mineralization was examined. Higher concentrations than those found in the aquatic environment were tested in order to clearly show the viability of SPEF for its removal. Intermediates were detected by gas chromatography-mass spectrometry (GC-MS) and generated short-chain aliphatic carboxylic acids were quantified by high-performance liquid chromatography (HPLC). The transformation of the initial $\mathrm{N}$ atom of ERY was assessed as well.

\section{Description of the SPEF flow plant}

Fig. 2 shows a scheme of the setup of the recirculation SPEF flow plant with an FM01-LC electrochemical reactor coupled to a CPC photoreactor and a mixing reservoir that contains $10 \mathrm{dm}^{3}$ of the elec- 


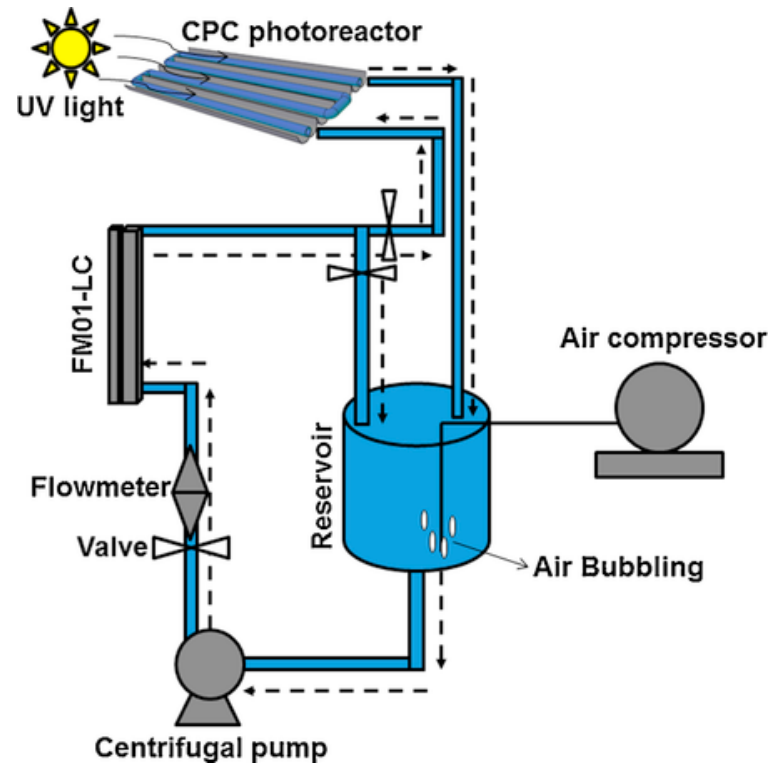

Fig. 2. Setup of the flow system employed for the SPEF treatment of ERY.

trolytic solution. The solution was pumped by a centrifugal pump to pass through the FM01-LC and CPC before returning to the reservoir.

The characteristics of the FM01-LC reactor are given in Table 1 and a scheme has been presented elsewhere [45]. Many researchers have used this versatile laboratory-scale reactor to quantify the importance of reaction environment in fundamental studies and to develop industrial applications $[45,52]$. The FM01-LC was equipped with a platinized Ti plate anode (purpose made following the Pechini method) and a GF cathode, with $0.4 \mathrm{~cm}$ thickness and $10-100 \times 10^{-3} \Omega^{-1} \mathrm{~cm}^{-1}$ electrical conductivity, provided by ROOE Group. A stainless steel plate of $4.0 \mathrm{~cm}$ in height, $16.0 \mathrm{~cm}$ in length and $0.3 \mathrm{~cm}$ in thickness was used as cathodic collector. The electrical contact between stainless steel and GF was ensured by gluing them with conducting carbon cement (Leit-C from Agar Aids). A polypropylene routed mesh, promoter type D [45], was used as turbulence promoter between the anode and cathode.

The CPC photoreactor had a concentration factor of 1 and consisted of 4 acrylic tubes with an irradiated volume of $1.4 \mathrm{dm}^{3}$. It was mounted on an aluminum frame platform tilted $21^{\circ}$ and oriented to the south to directly collect the sun rays at the University of Guanajuato (latitude: $21.03^{\circ} \mathrm{N}$, longitude: $101.25^{\circ} \mathrm{W}$ ). The CPC photoreactor was rigorously designed and constructed by us according the required design criteria [54-56].

Table 1

Dimensions of the FM01-LC electrochemical reactor.

\begin{tabular}{ll}
\hline Electrode height (B) & $4.0 \mathrm{~cm}$ \\
Electrode spacing (S) & $0.55 \mathrm{~cm}$ \\
Electrode length (L) & $16 \mathrm{~cm}^{-1}$ \\
Volumetric area GF (a) & $517 \mathrm{~cm}^{-1}$ \\
Platinized Ti plate anode area & $64 \mathrm{~cm}^{2}$ \\
Turbulence promoter & Plastic mesh D; DC and DL ${ }^{\mathrm{b}}=11 \mathrm{~mm}$ \\
& 0.83 of overall voidage \\
Graphite felt (GF) & $0.4 \mathrm{~cm}$ (thickness), 0.97 (porosity)
\end{tabular}

${ }^{a}$ Internal dimension of the short diagonal of the mesh.

b Internal dimension of the long diagonal of the mesh.
3. Mathematical model for SPEF treatment of organics in a flow plant with ideal flow pattern deviations in batch recirculation mode

Addressing the mass transport, current and potential distributions in three dimensional electrodes, as is the case of the GF employed here, is a complex task, since the velocity fields and mass transport effects cannot be directly calculated [45]. One way to quantify them in $3 \mathrm{D}$ electrodes is by means of parametric models, which propose partial differential equations in one dimension in transient state [57]. The mass transport equations, in parametric models, include axial dispersion parameters that are experimentally obtained by analysis of the residence time distribution (RTD) considering ideal flow deviations such as stagnant and low velocity zones, channeling and recirculation of the flow, among others [45]. In this context, here we expand a parametric model to describe the mineralization of ERY (including the formed by-products and intermediates) in a SPEF flow plant.

The DOC decay from ERY solutions treated in this work obeys the complex SPEF process, which involves several reaction steps and kinetic constants such as the electrogeneration of $\mathrm{H}_{2} \mathrm{O}_{2}$, the Fenton's reaction, photocatalytic reactions and hydroxylation/dehydrogenation of the compounds leading to the formation of complex organic by-products and radicals during the mineralization, among others [22-25]. In order to construct a model that describes the gradual depletion of the DOC over time in batch recirculation mode, we utilized: (i) the dispersion model expression for the FM01-LC, (ii) the dispersion model with a global reaction rate term for the $\mathrm{CPC}$, and (iii) the mass balance equations in the continuous stirred tank (CST) in transient regime. The following assumptions were considered:

(i) The FM01-LC behaves as a flow-by electrochemical reactor in which the production of $\mathrm{H}_{2} \mathrm{O}_{2}$ from reaction (1) and the regeneration of $\mathrm{Fe}^{2+}$ from reaction (3) occur at the GF, whereas the massive $\mathrm{O}_{2}$ evolution reaction (OER) takes place in the platinized $\mathrm{Ti}$ anode. In the model, the mineralization of ERY, and formed by-products and intermediates within the reactor are neglected because: (a) heterogeneous $\mathrm{M}\left({ }^{\bullet} \mathrm{OH}\right)$ radicals are not formed at the anode due to the low $j$ used [58], and (b) the contribution by $\mathrm{H}_{2} \mathrm{O}_{2}$ is very small compared to SPEF reactions [59]. The later assumption is also considered owing to the very short residence times in the FM01-LC at the flow rates applied $(0.56<t<0.91 \mathrm{~s})$.

(ii) The use of a turbulence promoter type-D in the FM01-LC improves the mixing; therefore, the DOC variation only depends on the axial coordinate (1D).

(iii) The model assumes the liquid bulk phase and $\mathrm{O}_{2}$ gas formed at the anode of the FM01-LC as a pseudo-homogenous phase since the turbulence promoter type-D quickly breaks the gas bubbles.

(iv) The CPC is considered the heart for SPEF because the degradation of organics can be accelerated by simultaneous irradiation with UV light coming from sunlight favoring the photolytic reactions (5) and (6), as previously reported by some of us [42]. The dispersion model with a global mineralization rate term for the CPC is considered.

(v) The CPC volume $\left(1400 \mathrm{~cm}^{3}\right)$ is very large compared with the FM01-LC $\left(35 \mathrm{~cm}^{3}\right)$. The residence times in the CPC, at the flow rates studied here, varied between 22.72 and $36.55 \mathrm{~s}$, which are higher than those in the FM01-LC. This corroborates the predominance of the DOC mineralization in the CPC photoreactor of the plant.

(vi) The reservoir tank is considered a perfectly mixed CST. 
(vii) The SPEF flow plant system is isothermal.

The mass balance for the FM01-LC reactor considers an ideal flow pattern deviation, which can be described by a plug flow with axial dispersion model. A 1D partial differential mass balance equation ( $y$-coordinate) can then be expressed as follows [57]:

$$
\frac{\partial C_{1}}{\partial t}=D_{a x 1} \frac{\partial^{2} C_{1}}{\partial y^{2}}-\frac{U_{01}}{\varepsilon} \frac{\partial C_{1}}{\partial y}
$$

where $C_{1}$ is the DOC value of the solution, $t$ is the time of the mineralization experiment, $D_{\mathrm{ax} 1}$ is the axial dispersion coefficient (i.e., longitudinal dispersion coefficient) obtained from the RTD experiments in the FM01-LC [60], $U_{01}$ is the mean inflow velocity at the entrance of the cell and $\varepsilon$ is the void fraction of the GF. $D_{\mathrm{ax} 1}$ allows quantifying the non-ideal flow deviations such as the retro-mixing degree during the flow stream.

The mass balance for the CPC photoreactor considers the reaction term as a global mineralization rate involving the ERY oxidation via homogeneous ${ }^{\bullet} \mathrm{OH}$ in the bulk and formed by-products and intermediates in terms of the DOC concentration. A differential mass balance in the CPC yields the following partial differential equation:

$$
\frac{\partial C_{2}}{\partial t}=D_{a x 2} \frac{\partial^{2} C_{2}}{\partial x^{2}}-U_{02} \frac{\partial C_{2}}{\partial x}-k_{a p p} C 2^{n}
$$

where $C_{2}$ is the DOC value of the ERY solution inside the CPC, $t$ is the time of the mineralization experiment, $D_{\mathrm{ax} 2}$ is the axial dispersion coefficient obtained from the RTD experiments in the photoreactor [60], $U_{02}$ is the mean inflow velocity at the entrance of the CPC, $k_{\text {app }}$ is the apparent global kinetic constant and $n$ is the reaction order.

Finally, the differential mass balance within the CST, neglecting a reaction term, can be expressed as follows [57]:

$$
\frac{\partial C_{0}}{\partial t}=\frac{Q}{V_{T}}\left(C_{2}(t . L)-C_{0}\right)
$$

where $V_{\mathrm{T}}$ is the reservoir volume, $Q$ is the volumetric flow rate, $C_{2}$ is the DOC value of the solution at the outlet of the CPC photoreactor, feeding the reservoir, and $C_{0}$ is the outlet DOC value at time $t$ from the reservoir, feeding the FM01-LC reactor. It is important to highlight that he reservoir acts as a mixer tank and thus, $C_{0}$ has the same value in all the points.
Eqs. (7)-(9) were solved via finite element method using the boundary conditions for a closed-closed vessel system [61], as schematized in Fig. 3 for the SPEF flow plant used. For the FM01-LC reactor, the boundary conditions to solve Eq. (7) are as follows:

$$
\begin{aligned}
& \text { At } \mathrm{y}=0 C_{1}=C_{0} \\
& \text { At } y=H, \frac{\partial C_{1}}{\partial y}=0
\end{aligned}
$$

where $H$ is the electrode height. To solve Eq. (8) for the CPC, the boundary conditions are:

$$
\begin{aligned}
& \text { At } x=0, C_{2}=C_{1}(t, H) \\
& \text { At } x=L, \frac{\partial C_{2}}{\partial x}=0
\end{aligned}
$$

where $L$ is the total CPC photoreactor length. The solution of Eq. (9) for the CST requires the following initial boundary conditions:

$$
\text { At } t=0, C_{0}(0)=C^{*}
$$

where $C^{*}$ is the initial DOC value. It is important to remember that the CST acts as a perfect mixer; thus, $C_{0}$ is assumed to be the same in any point inside the reservoir including the outlet. In order to obtain a complete solution of the mathematical model, it is necessary to set the following initial conditions for Eqs. (7) and (8):

$$
\text { At } t=0, C_{1}(0, y)=C^{*}
$$

$$
\text { At } t=0, C_{2}(0, x)=C^{*}
$$

In this parametric model, the reaction order that better fitted the experimental DOC-time curves was $n=0$, as determined after several simulation trials. Table 2 summarizes the electrolyte properties and parameters used in the numerical simulation. Table 3 collects the dispersion modules for the FM01-LC and CPC reactors used in the numerical calculations, based on RTD analysis in each reactor [60]. Table 4 shows the $k_{\text {app }}$ values obtained from numerical fitting of the experimental DOC-time plots. It is important to highlight that real ef-

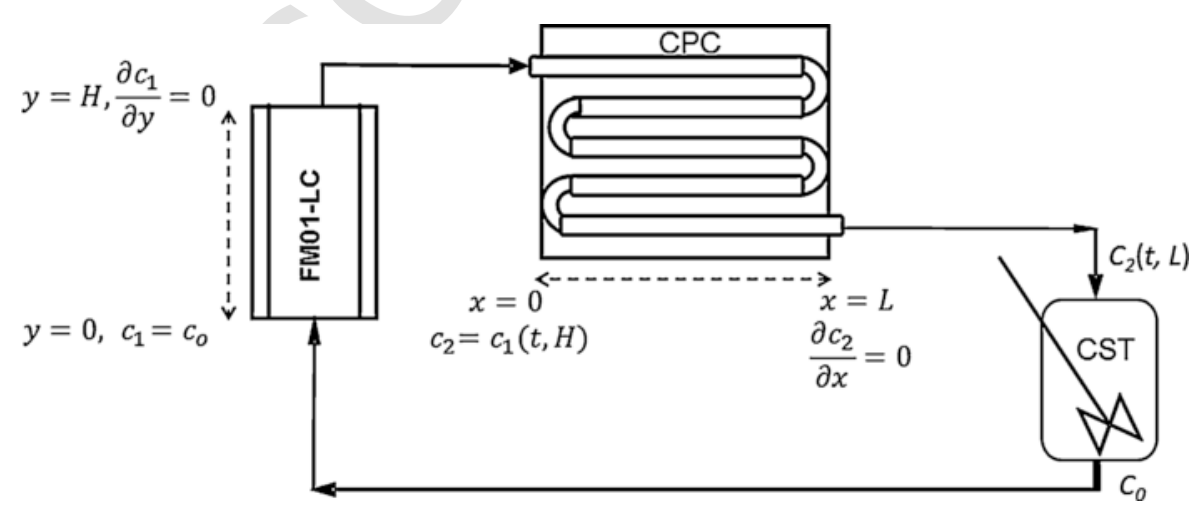

Fig. 3. Boundary conditions adopted in the numerical calculations of the parametric model. 
Table 2

Electrolyte properties and transport parameters used in the numerical simulation at $293 \mathrm{~K}$.

\begin{tabular}{|c|c|}
\hline \multirow{3}{*}{$\begin{array}{l}\text { Dispersion coefficient of the FM01-LC, } \\
D_{\mathrm{ax} 1}\end{array}$} & $62.5 \mathrm{~cm}^{2} \mathrm{~s}^{-1}$ (at $2.3 \mathrm{dm}^{3} \mathrm{~min}^{-1}$ ) \\
\hline & $151.4 \mathrm{~cm}^{2} \mathrm{~s}^{-1}$ (at $3.0 \mathrm{dm}^{3} \mathrm{~min}^{-1}$ ) \\
\hline & $296.5 \mathrm{~cm}^{2} \mathrm{~s}^{-1}$ (at $3.7 \mathrm{dm}^{3} \mathrm{~min}^{-1}$ ) \\
\hline \multirow{3}{*}{ Dispersion coefficient of the CPC, $D_{\mathrm{ax} 2}$} & $224 \mathrm{~cm}^{2} \mathrm{~s}^{-1}$ (at $2.3 \mathrm{dm}^{3} \mathrm{~min}^{-1}$ ) \\
\hline & $745 \mathrm{~cm}^{2} \mathrm{~s}^{-1}$ (at $\left.3.0 \mathrm{dm}^{3} \mathrm{~min}^{-1}\right)$ \\
\hline & $1310 \mathrm{~cm}^{2} \mathrm{~s}^{-1}$ (at $3.7 \mathrm{dm}^{3} \mathrm{~min}^{-1}$ ) \\
\hline \multirow[t]{3}{*}{ Mean inflow velocity at the FM01-LC, $U_{01}$} & $23.95 \mathrm{~cm} \mathrm{~s}^{-1}$ (at $2.3 \mathrm{dm}^{3} \mathrm{~min}^{-1}$ ) \\
\hline & $31.25 \mathrm{~cm} \mathrm{~s}^{-1}$ (at $\left.3.0 \mathrm{dm}^{3} \mathrm{~min}^{-1}\right)$ \\
\hline & $42.29 \mathrm{~cm} \mathrm{~s}^{-1}$ (at $\left.3.7 \mathrm{dm}^{3} \mathrm{~min}^{-1}\right)$ \\
\hline \multirow[t]{3}{*}{ Mean inflow velocity at the $\mathrm{CPC}, U_{02}$} & $13.1 \mathrm{~cm} \mathrm{~s}^{-1}$ (at $2.3 \mathrm{dm}^{3} \mathrm{~min}^{-1}$ ) \\
\hline & $17.6 \mathrm{~cm} \mathrm{~s}^{-1}$ (at $3.0 \mathrm{dm}^{3} \mathrm{~min}^{-1}$ ) \\
\hline & $22.2 \mathrm{~cm} \mathrm{~s}^{-1}$ (at $3.7 \mathrm{dm}^{3} \mathrm{~min}^{-1}$ ) \\
\hline Solution volume, $V_{\mathrm{T}}$ & $10,000 \mathrm{~cm}^{3}$ \\
\hline Total CPC photoreactor length, $L$ & $407 \mathrm{~cm}$ \\
\hline FM01-LC electrode height, $H$ & $16 \mathrm{~cm}$ \\
\hline Graphite porosity, $\varepsilon$ & 0.97 \\
\hline \multirow[t]{3}{*}{ DOC initial concentration, $C^{*}$} & $\left.4.165 \times 10^{-6} \mathrm{~mol} \mathrm{~cm}^{-3}(50 \mathrm{mg} \mathrm{dm})^{-3}\right)$ \\
\hline & $8.33 \times 10^{-6} \mathrm{~mol} \mathrm{~cm}^{-3}\left(100 \mathrm{mg} \mathrm{dm}^{-3}\right)$ \\
\hline & $1.25 \times 10^{-6} \mathrm{~mol} \mathrm{~cm}^{-3}\left(150 \mathrm{mg} \mathrm{dm}^{-3}\right)$ \\
\hline
\end{tabular}

Table 3

Dispersion modules for the FM01-LC and the CPC at different volumetric flow rates [60].

\begin{tabular}{lll}
\hline & FM01-LC & CPC \\
$Q\left(\mathrm{dm}^{3} \mathrm{~min}^{-1}\right)$ & $D_{\mathrm{ax} 1} / U_{\mathrm{o} 1} H$ & $D_{\mathrm{ax} 2} / U_{\mathrm{o} 2} L$ \\
\hline 2.3 & 0.17 & 0.042 \\
3.0 & 0.30 & 0.104 \\
3.7 & 0.47 & 0.145 \\
\hline
\end{tabular}

fluents are composed of several types of emerging pollutants. Hence, from the engineering standpoint only the high reduction of DOC (measured as soluble TOC) or COD or $\mathrm{BOD}_{5}$ allied to a low energy demand, deserves special attention for practical purposes. This is the reason to develop the present model in terms of the total content of DOC during the SPEF process. Therefore, the monitoring of ERY concentration over time was out of the scope of this paper.

The parametric global model was solved using COMSOL Multiphysics ${ }^{\circledR} 5.1$ software considering 40,700 lineal elements, and employing a workstation with 2 Intel $^{\circledR}$ Xeon $2.3 \mathrm{GHz}$ processors and
96 GB of RAM. Simulation run times were typically around $90 \mathrm{~s}$ and the numerical error was below $0.001 \%$.

\section{Experimental}

\subsection{Chemicals}

Erythromycin was of analytical standard grade purchased from Sigma-Aldrich and was used as received. Anhydrous $\mathrm{Na}_{2} \mathrm{SO}_{4}$ used as background electrolyte and heptahydrated $\mathrm{FeSO}_{4}$ used as catalyst for Fenton's reaction were of analytical grade supplied by Fermont. Solutions were prepared with deionized water and their $\mathrm{pH}$ was adjusted with analytical grade $\mathrm{H}_{2} \mathrm{SO}_{4}$ purchased from Sigma-Aldrich. Carboxylic acids and other chemicals and solvents of either HPLC or analytical grade were supplied by Sigma-Aldrich, Fermont and Fluka. All standard solutions and mobile phases were prepared with high-purity HPLC water supplied by Sigma-Aldrich.

\subsection{Mineralization experiments in the SPEF flow plant}

The electrolyte was recirculated using a Little Giant 4MDHC non-submersible centrifugal pump at volumetric flow rates $(Q)$ of 2.3 , 3.0 , and $3.7 \mathrm{dm}^{3} \mathrm{~min}^{-1}$, adjusted with a flowmeter, whereas the solution temperature was kept at around $35^{\circ} \mathrm{C}$. All connections, tubes and pipes were made of PVC hydraulic plastic.

Oxygen gas was continuously supplied via air sparging into the reservoir with an air diffusion ceramic connected to a Dewalt D55168 air compressor at a constant pressure of 0.7 bar, reaching a maximum of concentration of $7.8 \mathrm{mg} \mathrm{dm}^{-3}\left(0.25 \mathrm{mmol} \mathrm{dm}^{-3}\right)$. Under such experimental conditions, the solution was saturated with $\mathrm{O}_{2}$ for $\mathrm{H}_{2} \mathrm{O}_{2}$ generation from reaction (1). The dissolved $\mathrm{O}_{2}$ content was determined with a Hanna HI 9142 dissolved oxygen meter. The current was supplied by a BK Precision 1621A power source, which directly displayed the potential difference between the electrodes. The electrode potentials were measured against a saturated sulfate reference electrode (SSE), inserted into a Luggin capillary, using an Agilent 34410 high impedance multimeter. All electrode potentials in this work are referred to the standard hydrogen electrode (SHE).

Prior to each mineralization experiment, $\mathrm{H}_{2} \mathrm{O}_{2}$ was previously generated into the $0.050 \mathrm{~mol} \mathrm{dm}^{-3} \mathrm{Na}_{2} \mathrm{SO}_{4}$ solution for $2 \mathrm{~h}$ without solar radiation, reaching a maximum $\mathrm{H}_{2} \mathrm{O}_{2}$ concentration of $50.3 \mathrm{mg} \mathrm{dm}{ }^{-3}$ at $j=0.16 \mathrm{~mA} \mathrm{~cm}^{-2}$ and constant $Q=3.0 \mathrm{dm}^{3} \mathrm{~min}^{-1}$. This methodology

Table 4

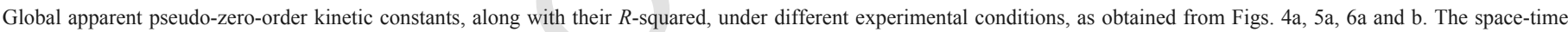
yields evaluated at the end of the electrolyses are also presented.

\begin{tabular}{|c|c|c|c|c|c|c|c|}
\hline Fig. $4 \mathrm{a}$ & & & & Fig. 5a & & & \\
\hline $\begin{array}{l}{\left[\mathrm{Fe}^{2+}\right]} \\
(\mathrm{mmol} \mathrm{dm}\end{array}$ & $\begin{array}{l}k_{\text {app }} \\
\left(\mathrm{mol} \mathrm{cm}^{-3} \mathrm{~s}^{-1}\right)\end{array}$ & $R^{2}$ & $\begin{array}{l}\rho_{\mathrm{ST}} \\
\left(\mathrm{g} \mathrm{dm}^{-3} \mathrm{~s}^{-1}\right)\end{array}$ & $\begin{array}{l}j \\
\left(\mathrm{~mA} \mathrm{~cm}^{-2}\right)\end{array}$ & $\begin{array}{l}k_{\text {app }} \\
\left(\mathrm{mol} \mathrm{cm} \mathrm{cm}^{-3} \mathrm{~s}^{-1}\right)\end{array}$ & $R^{2}$ & $\begin{array}{l}\rho_{\mathrm{ST}} \\
\left(\mathrm{g} \mathrm{dm}^{-3} \mathrm{~s}^{-1}\right)\end{array}$ \\
\hline $\begin{array}{l}0.25 \\
0.50 \\
1.00\end{array}$ & $\begin{array}{l}2.0 \times 10^{-9} \\
4.0 \times 10^{-9} \\
2.5 \times 10^{-9}\end{array}$ & $\begin{array}{l}0.98 \\
0.97 \\
0.96\end{array}$ & $\begin{array}{l}2.5 \times 10^{-4} \\
2.8 \times 10^{-4} \\
3.9 \times 10^{-4}\end{array}$ & $\begin{array}{l}0.075 \\
0.14 \\
0.16 \\
0.18 \\
0.23\end{array}$ & $\begin{array}{l}1.1 \times 10^{-9} \\
2.5 \times 10^{-9} \\
3.0 \times 10^{-9} \\
2.5 \times 10^{-9} \\
1.1 \times 10^{-9}\end{array}$ & $\begin{array}{l}0.99 \\
0.92 \\
0.98 \\
0.93 \\
0.98\end{array}$ & $\begin{array}{l}1.2 \times 10^{-4} \\
3.1 \times 10^{-4} \\
3.5 \times 10^{-4} \\
2.9 \times 10^{-4} \\
1.1 \times 10^{-4}\end{array}$ \\
\hline Fig. 6a & & & & Fig. 6b & & & \\
\hline $\begin{array}{l}Q \\
\left(\mathrm{dm}^{3} \min ^{-1}\right)\end{array}$ & $\begin{array}{l}k_{\mathrm{app}}^{\mathrm{a}} \\
\left(\mathrm{mol} \mathrm{cm} \mathrm{cm}^{-3} \mathrm{~s}^{-1}\right)\end{array}$ & $R^{2}$ & $\begin{array}{l}\rho_{\mathrm{ST}} \\
\left(\mathrm{g} \mathrm{dm}^{-3} \mathrm{~s}^{-1}\right)\end{array}$ & $\begin{array}{l}\mathrm{DOC}_{0} \\
\left(\mathrm{mg} \mathrm{dm}^{-3}\right)\end{array}$ & $\begin{array}{l}k_{\text {app }} \\
\left(\mathrm{mol} \mathrm{cm}^{-3} \mathrm{~s}^{-1}\right)\end{array}$ & $R^{2}$ & $\begin{array}{l}\rho_{\mathrm{ST}} \\
\left(\mathrm{g} \mathrm{dm}^{-3} \mathrm{~s}^{-1}\right)\end{array}$ \\
\hline $\begin{array}{l}2.3 \\
3.0 \\
3.7\end{array}$ & $3.0 \times 10^{-9}$ & 0.98 & $\begin{array}{l}2.0 \times 10^{-4} \\
3.5 \times 10^{-4} \\
4.0 \times 10^{-4}\end{array}$ & $\begin{array}{l}50 \\
100 \\
150\end{array}$ & $\begin{array}{l}2.1 \times 10^{-9} \\
3.0 \times 10^{-9} \\
2.4 \times 10^{-9}\end{array}$ & $\begin{array}{l}0.98 \\
0.98 \\
0.92\end{array}$ & $\begin{array}{l}2.1 \times 10^{-4} \\
3.5 \times 10^{-4} \\
3.0 \times 10^{-4}\end{array}$ \\
\hline
\end{tabular}

a The values at 2.3 and $3.7 \mathrm{dm}^{3} \mathrm{~min}^{-1}$ are not shown because of the unclear linear trend. 
was based on one our most recent works [59]. The $\mathrm{H}_{2} \mathrm{O}_{2}$ concentration was determined using the light absorption of the titanic-hydrogen peroxide colored complex at $\lambda=408 \mathrm{~nm}$ [62], using a Perkin Elmer Lambda $35 \mathrm{UV} / \mathrm{V}$ is spectrophotometer. After $\mathrm{H}_{2} \mathrm{O}_{2}$ pre-accumulation, a given amount of the drug was added to the solution and dissolved upon several minutes of recirculation, thereafter running the electrolysis. The SPEF trials were carried out for $300 \mathrm{~min}$ in sunny days during the autumn of 2015. The average daily UV solar irradiation intensity from 300 to $400 \mathrm{~nm}$ was around $55 \mathrm{~W} \mathrm{~m}^{-2}$, as determined by a weather station located at the University of Guanajuato.

\subsection{Apparatus and analytical procedures}

The solution $\mathrm{pH}$ was determined with a Hanna HI991300 pH-meter. The samples withdrawn from treated solutions were alkalinized to stop the ${ }^{-} \mathrm{OH}$ production and hence, the mineralization process. They were filtered with $0.45 \mu \mathrm{m}$ PTFE filters before analysis. The mineralization of ERY solutions was monitored from their DOC removal, determined on a Tekmar Torch TOC analyzer. Reproducible DOC values with an accuracy of $\pm 1 \%$ were obtained by injecting $40 \mu \mathrm{L}$ aliquots into the analyzer. Generated carboxylic acids were detected by ion-exclusion HPLC using a Perkin Elmer Flexar LC fitted with an Agilent Hi-Plex H $8 \mu \mathrm{m}, 300 \mathrm{~mm} \times 7.7 \mathrm{~mm}$ (i.d.), column at room temperature and coupled with a Flexar photodiode array detector set at $\lambda=210.0 \mathrm{~nm}$. These measurements were performed by injecting $20 \mu \mathrm{L}$ samples into the LC using $5 \mathrm{mmol} \mathrm{dm}{ }^{-3} \mathrm{H}_{2} \mathrm{SO}_{4}$ as mobile phase at $0.6 \mathrm{~cm}^{3} \mathrm{~min}^{-1}$. Ion-exclusion chromatograms exhibited peaks related to oxalic, maleic, oxamic, fumaric and formic acids at retention times of 7.6, 9.6, 10.9, 14.7 and $19.8 \mathrm{~min}$, respectively. Analysis of $\mathrm{NO}_{3}{ }^{-}$by ion chromatography was carried out by injecting $100 \mu \mathrm{L}$ aliquots into the above LC, equipped with a Hamilton PRP-X110, $150 \mathrm{~mm} \times 4.1 \mathrm{~mm}$ (i.d.), anionic column at room temperature and coupled to an Adept Cecil CE4710 conductivity detector. A mixture of a $4 \mathrm{mmol} \mathrm{dm}^{-3} p$-hydroxybenzoic acid, $0.1 \mathrm{mmol} \mathrm{dm}^{-3}$ $\mathrm{NaSCN}$ and $2.5 \%$ methanol at $\mathrm{pH} 8.5$ was circulated at $1 \mathrm{~cm}^{3} \mathrm{~min}^{-1}$ as mobile phase. The $\mathrm{NH}_{4}{ }^{+}$content was determined with an Alpkem Flow Solution IV flow injection system through colorimetric analysis based on the standard indophenol blue reaction.

Intermediates formed at 30 and 120 min of the SPEF degradation of a $0.225 \mathrm{mmol} \mathrm{dm}^{-3}$ ERY solution in $0.050 \mathrm{~mol} \mathrm{dm}^{-3} \mathrm{Na}_{2} \mathrm{SO}_{4}$ at $\mathrm{pH}$ 3.0 and $j=0.16 \mathrm{~mA} \mathrm{~cm}^{-2}$ were identified by GC-MS. About $100 \mathrm{~cm}^{3}$ aliquots were lyophilized or extracted out with $\mathrm{CH}_{2} \mathrm{Cl}_{2}\left(3 \times 25 \mathrm{~cm}^{3}\right)$. After lyophilization, the residue was dissolved in $1 \mathrm{~cm}^{3}$ of ethyl acetate, whereas after $\mathrm{CH}_{2} \mathrm{Cl}_{2}$ extraction, the organic volume was reduced to about $1 \mathrm{~cm}^{3}$ after drying over anhydrous $\mathrm{Na}_{2} \mathrm{SO}_{4}$ followed by filtration. GC-MS analysis of concentrated samples was carried out on an Agilent system composed of a $6890 \mathrm{~N}$ GC with a $7683 \mathrm{~B}$ series injector and a $5975 \mathrm{C} \mathrm{MS}$ in EI mode at $70 \mathrm{eV}$. The GC was fitted with a non-polar Teknokroma Sapiens-X5 ms $0.25 \mu \mathrm{m}, 30 \mathrm{~m} \times 0.25 \mathrm{~mm}$ (i.d.), column. The temperature ramp was: $36^{\circ} \mathrm{C}$ for $1 \mathrm{~min}, 5^{\circ} \mathrm{C} \mathrm{min}{ }^{-1}$ up to $325^{\circ} \mathrm{C}$ and hold time $10 \mathrm{~min}$. The temperature of the inlet, source and transfer line was 250,230 and $300^{\circ} \mathrm{C}$, respectively. The analysis was always made by splitless $(0.7 \mathrm{~min})$ injection. A NIST05-MS library was used to interpret the mass spectra.

\section{Results and discussion}

\subsection{Effect of catalyst content on the SPEF process under potentiostatic conditions}

A first series of experiments in the SPEF flow plant was performed by comparatively degrading $10 \mathrm{dm}^{3}$ of a $0.225 \mathrm{mmol} \mathrm{dm}^{-3}$ (100 mg dm ${ }^{-3}$ DOC) ERY solution in $0.050 \mathrm{~mol} \mathrm{dm}^{-3} \mathrm{Na}_{2} \mathrm{SO}_{4}$ with catalytic $\mathrm{Fe}^{2+}$ concentration between 0.25 and $1.00 \mathrm{mmol} \mathrm{dm}^{-3}$ at $\mathrm{pH}$ 3.0 and $Q=3.0 \mathrm{dm}^{3} \mathrm{~min}^{-1}$ for $300 \mathrm{~min}$. These trials were run at a constant cathodic potential $\left(E_{\text {cat }}\right)$ of $-0.35 \mathrm{~V}$ vs SHE in order to ensure a constant $\mathrm{H}_{2} \mathrm{O}_{2}$ production without $\mathrm{H}_{2}$ evolution reaction (HER), following the recommendations widely explained in our recent publication focused on the optimization of $\mathrm{H}_{2} \mathrm{O}_{2}$ electrogeneration [53].

Fig. 4a exemplifies the practically linear DOC decays with electrolysis time determined for the above experiments. The mineralization rate was enhanced when the $\mathrm{Fe}^{2+}$ content was increased from 0.25 to $0.50 \mathrm{mmol} \mathrm{dm}^{-3}$, as expected if larger amounts of $\bullet \mathrm{OH}$ are generated from Fenton's reaction (2) due to the presence of a higher quantity of catalyst. In contrast, further increase to $1.00 \mathrm{mmol} \mathrm{dm}{ }^{-3} \mathrm{Fe}^{2+}$ caused a progressive drop in DOC abatement at each given time. This can be accounted for by the gradually larger extent to which the parasitic reaction (10) is given, which entails a large consumption of generated ${ }^{\bullet} \mathrm{OH}$ by the excess of $\mathrm{Fe}^{2+}$ ion added, thus decelerating the mineralization process [22-25]. Note that, despite the much larger rate constant of reaction (10) compared to that of Fenton's reaction (2), the former one is significant only once the production rate of $\mathrm{H}_{2} \mathrm{O}_{2}$ from reaction (1) becomes insufficient to consume the excessive amount of $\mathrm{Fe}^{2+}$. The best performance was then obtained at an optimum concentration of $0.50 \mathrm{mmol} \mathrm{dm}{ }^{-3} \mathrm{Fe}^{2+}$, attaining $78 \%$ DOC reduction at the end of the trial.

$$
\mathrm{Fe}^{2+}+\cdot \mathrm{OH} \rightarrow \mathrm{Fe}^{3+}+\mathrm{OH}^{-}
$$

Assuming that the total cold combustion of ERY (including formed by-products and intermediates) leads to the formation of $\mathrm{CO}_{2}$ and $\mathrm{NO}_{3}^{-}$as major ion, as will be discussed below, its theoretical total mineralization reaction can be written as follows:

$$
\begin{aligned}
& \mathrm{C}_{37} \mathrm{H}_{67} \mathrm{NO}_{13}+64 \mathrm{H}_{2} \mathrm{O} \rightarrow 37 \\
& \mathrm{CO}_{2}+\mathrm{NO}_{3}^{-}+195 \mathrm{H}^{+}+194 \mathrm{e}^{-}
\end{aligned}
$$

Although a large number of protons was produced, the solution $\mathrm{pH}$ remained almost constant because of their consumption in $\mathrm{H}_{2} \mathrm{O}_{2}$ electrogeneration from reaction (1).

The mineralization current efficiency (MCE, in \%) was then estimated from Eq. (12):

$$
\% \mathrm{MCE}=\frac{n F V_{S} \Delta(D O C)_{\exp }}{m Q_{t}} \times 100
$$

where $n$ is the number of electrons involved in the mineralization process (=194 from reaction (11)), $F$ is the Faraday constant $\left(96,487 \mathrm{C} \mathrm{mol}^{-1}\right), V_{\mathrm{S}}$ is the solution volume (in $\left.\mathrm{dm}^{3}\right), \Delta(\mathrm{DOC})_{\exp }$ is the experimental DOC abatement (in $\mathrm{g} \mathrm{dm}^{-3}$ ), $m$ is the total mass of carbon (in $\mathrm{g}$ ) per mol of ERY and $Q_{t}$ is the applied charge at electrolysis time $t$ (in $\mathrm{C}$ ). The specific energy consumption per unit DOC mass $\left(\mathrm{EC}_{\mathrm{DOC}}\right)$ was determined as follows: 


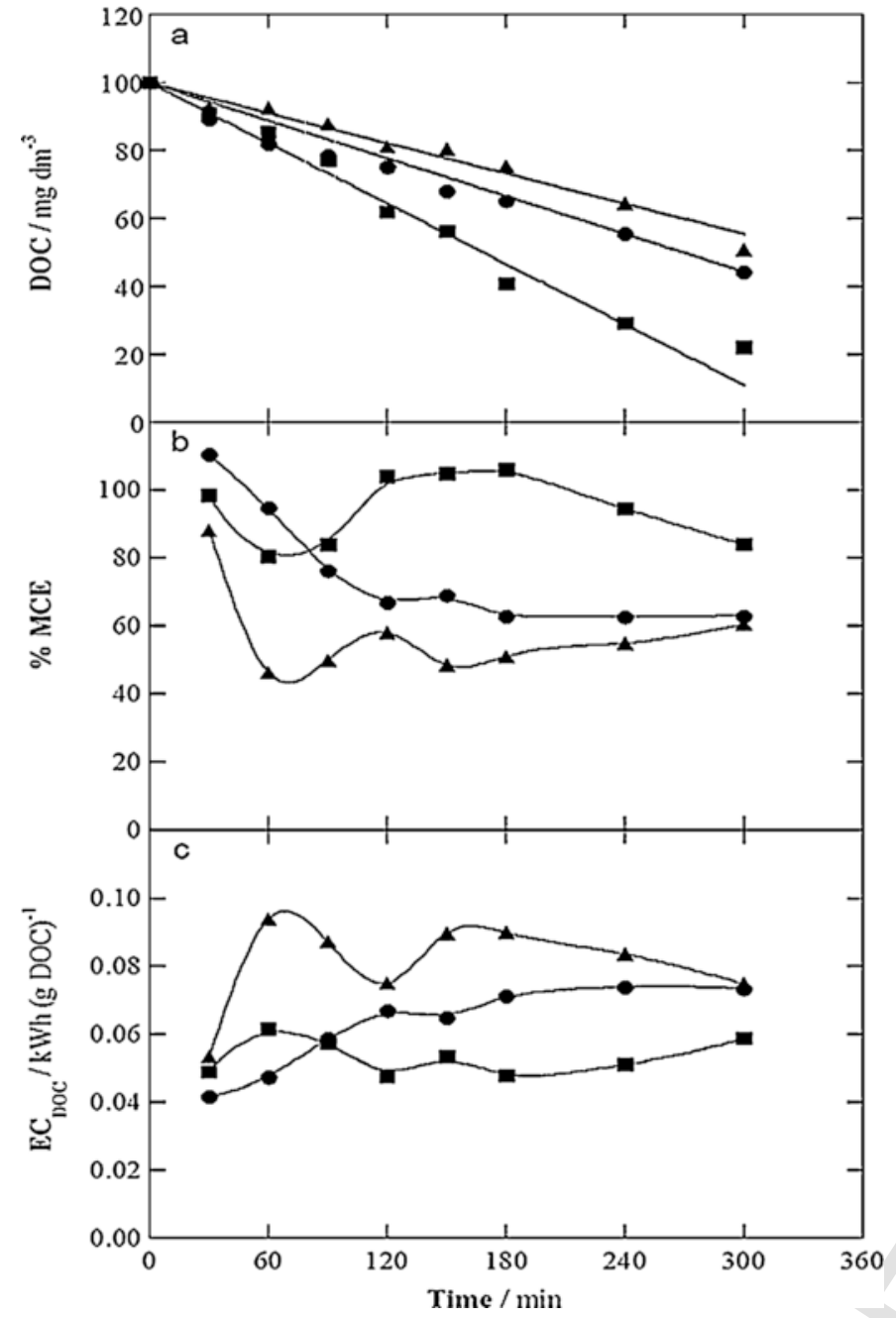

Fig. 4. Change of (a) DOC, (b) mineralization current efficiency and (c) specific energy consumption per gram of DOC with electrolysis time for the SPEF treatments

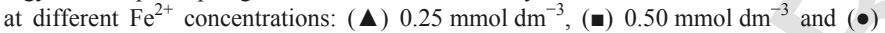
$1.00 \mathrm{mmol} \mathrm{dm}^{-3}$. Trated solution: $100 \mathrm{mg} \mathrm{dm}^{-3}$ DOC of ERY $\left(0.225 \mathrm{mmol} \mathrm{dm}{ }^{-3}\right.$ ERY) with $0.050 \mathrm{~mol} \mathrm{dm}^{-3} \mathrm{Na}_{2} \mathrm{SO}_{4}$ at $\mathrm{pH}=3.0$. Volumetric flow rate $Q=3.0 \mathrm{dm}^{3} \mathrm{~min}^{-1}$. Potential applied to the graphite-felt (GF) cathode $E_{\text {cat }}=-0.35 \mathrm{~V}$ vs SHE. Solid lines (-) of Fig. 4a correspond to the theoretical trends obtained from the parametric model with the graphed parameter $\left(C_{0}\right)$ being the DOC.

$$
\mathrm{EC}_{\mathrm{DOC}}\left(\mathrm{kWh}(\mathrm{g} \mathrm{DOC})^{-1}\right)=\frac{2.7 \times 10^{-7} E_{\text {cell }} Q_{\mathrm{t}}}{V_{S} \Delta(\mathrm{DOC})_{\exp }}
$$

where $2.7 \times 10^{-7}$ is a conversion factor for units homogenization (in $\mathrm{kWh} / \mathrm{Ws}$ ) and $E_{\text {cell }}$ is the potential difference between the anode and cathode (in V).

Fig. 4 b corroborates that $0.50 \mathrm{mmol} \mathrm{dm}{ }^{-3} \mathrm{Fe}^{2+}$ is the optimum catalyst concentration to perform the SPEF experiments. The use of this $\mathrm{Fe}^{2+}$ content yielded the highest MCE values between $80 \%$ and $106 \%$ throughout all the experiment, with a final value of $84 \%$. In contrast, much lower current efficiencies around $50-60 \%$ and $63-76 \%$ were obtained at 0.25 and $1.00 \mathrm{mmol} \mathrm{dm}^{-3}$, respectively, at times longer than $90 \mathrm{~min}$. Note that MCE values $>100 \%$ are feasible in SPEF because only the electrical contribution is considered in Eq. (12) and thus, the positive action of sunlight enhances the degradation at zero cost.
Higher mineralization current efficiencies gave rise to lower $\mathrm{EC}_{\mathrm{DOC}}$ values, as presented in Fig. 4c. For the optimum $0.50 \mathrm{mmol} \mathrm{dm}{ }^{-3} \mathrm{Fe}^{2+}$, an $\mathrm{EC}_{\mathrm{DOC}}=0.059 \mathrm{kWh}(\mathrm{g} \text { DOC })^{-1}$ was finally obtained.

Another important figure of merit to evaluate the performance of the system is the space-time yield (STY), $\rho_{\mathrm{ST}}$, defined in this case as the experimental DOC abatement per unit time [63]:

$$
\rho_{\mathrm{ST}}=\frac{\Delta(\mathrm{DOC})_{\mathrm{exp}}}{\tau_{\mathrm{ST}}}
$$

where $\tau_{S T}$ is the spatial time of the system $\left(V_{\mathrm{S}} / Q\right.$, in s). Table 4 shows the $\rho_{\mathrm{ST}}$ values for the different experimental conditions from Fig. $4 \mathrm{a}$, showing that the best performance in terms of STY was obtained at $0.50 \mathrm{mmol} \mathrm{dm}{ }^{-3} \mathrm{Fe}^{2+}$, confirming the above conclusion for $\mathrm{EC}_{\mathrm{DOC}}$.

\subsection{Effect of operation parameters on the SPEF process under galvanostatic conditions}

To better clarify the SPEF treatment of ERY solutions in the solar flow plant, the influence of important operation parameters like $j, Q$ and antibiotic concentration was assessed. The applied $j$ is a key operation variable in the EAOPs because it determines the quantity of generated oxidants. The influence of this parameter was ascertained by means of a second series of experiments with a $0.225 \mathrm{mmol} \mathrm{dm}^{-3}$ ERY solution at an optimum $0.50 \mathrm{mmol} \mathrm{dm}{ }^{-3} \mathrm{Fe}^{2+}$ concentration at $\mathrm{pH} 3.0$ by applying $j$ values of $0.14,0.16$, and $0.18 \mathrm{~mA} \mathrm{~cm}^{-2}(1.9,2.1$ and $2.3 \mathrm{~A}$ ), corresponding to $E_{\text {cat }}$ values between -0.4 and $-0.1 \mathrm{~V}$ vs SHE. This potential range favors the $\mathrm{H}_{2} \mathrm{O}_{2}$ formation from reaction (1) and avoids the parasitic HER, which takes place at $E_{\text {cat }}<-0.4 \mathrm{~V}$ vs SHE [53]. Two additional trials were conducted at 0.075 and $0.23 \mathrm{~mA} \mathrm{~cm}^{-2}$ ( 1 and $3 \mathrm{~A}$ ) related to $E_{\text {cat }}$ values less negative than $-0.1 \mathrm{~V}$ vs SHE and more negative than $-0.4 \mathrm{~V}$ vs SHE, respectively. In all these experiments, a $Q=3.0 \mathrm{dm}^{3} \mathrm{~min}^{-1}$ was utilized.

Fig. 5a shows the DOC depletion vs electrolysis time for the above trials. As can be seen, DOC was more rapidly removed by increasing $j$ from 0.075 to $0.16 \mathrm{~mA} \mathrm{~cm}^{-2}$, as expected if more $\mathrm{H}_{2} \mathrm{O}_{2}$ is gradually produced, therefore enhancing Fenton's reaction (2). This allows the production of a greater amount of ${ }^{\bullet} \mathrm{OH}$ in the bulk that can attack a larger quantity of organics, eventually upgrading the mineralization process. So, under these conditions, the $\mathrm{O}_{2}$ reduction to $\mathrm{H}_{2} \mathrm{O}_{2}$ via reaction (1) prevents the the parasitic HER [53]. In contrast, Fig. 5a highlights a progressive and dramatic drop of the DOC abatement when $j$ further grew to 0.18 and $0.23 \mathrm{~mA} \mathrm{~cm}^{-2}$, which might be attributed to the achievement of $E_{\text {cat }}$ values $<-0.4 \mathrm{~V}$ vs SHE, which increasingly promotes the parasitic HER ending in lower amounts of accumulated $\mathrm{H}_{2} \mathrm{O}_{2}$.

Fig. $5 \mathrm{~b}$ and $\mathrm{c}$ depicts the $\mathrm{MCE}$ and $\mathrm{EC}_{\mathrm{DOC}}$ values determined for the experiments of Fig. 5a. The highest mineralization current efficiencies between $74 \%$ and $110 \%$ and lowest specific energy consumptions between 0.041 and $0.063 \mathrm{kWh}(\mathrm{g} \text { DOC })^{-1}$ were found for $0.16 \mathrm{~mA} \mathrm{~cm}^{-2}$, leading to the highest DOC removal of $69 \%$. The MCE values at $0.075,0.14,0.16,0.018$ and $0.23 \mathrm{~mA} \mathrm{~cm}^{-2}$ at the end of the SPEF treatments were $58 \%, 77 \%, 75 \%, 62 \%$ and $18 \%$ respectively, whereas the corresponding $\mathrm{EC}_{\mathrm{DOC}}$ values were $0.063,0.058$, $0.059,0.077$ and $0.286 \mathrm{kWh}(\mathrm{g} \text { DOC })^{-1}$, respectively. Finally, Table 4 shows the STY values at the end of electrolysis from the data of Fig. 5a, where it can be seen that the best STY value was obtained at $0.16 \mathrm{~mA} \mathrm{~cm}^{-2}$, confirming what was previously discussed. All these results indicate that the SPEF treatment of a $0.225 \mathrm{mmol} \mathrm{dm}^{-3}$ ERY solution in $0.050 \mathrm{~mol} \mathrm{dm}^{-3} \mathrm{Na}_{2} \mathrm{SO}_{4}$ at $\mathrm{pH}=3.0$ under galvanostatic conditions becomes optimal operating with $0.50 \mathrm{mmol} \mathrm{dm}{ }^{-3} \mathrm{Fe}^{2+}$ at 


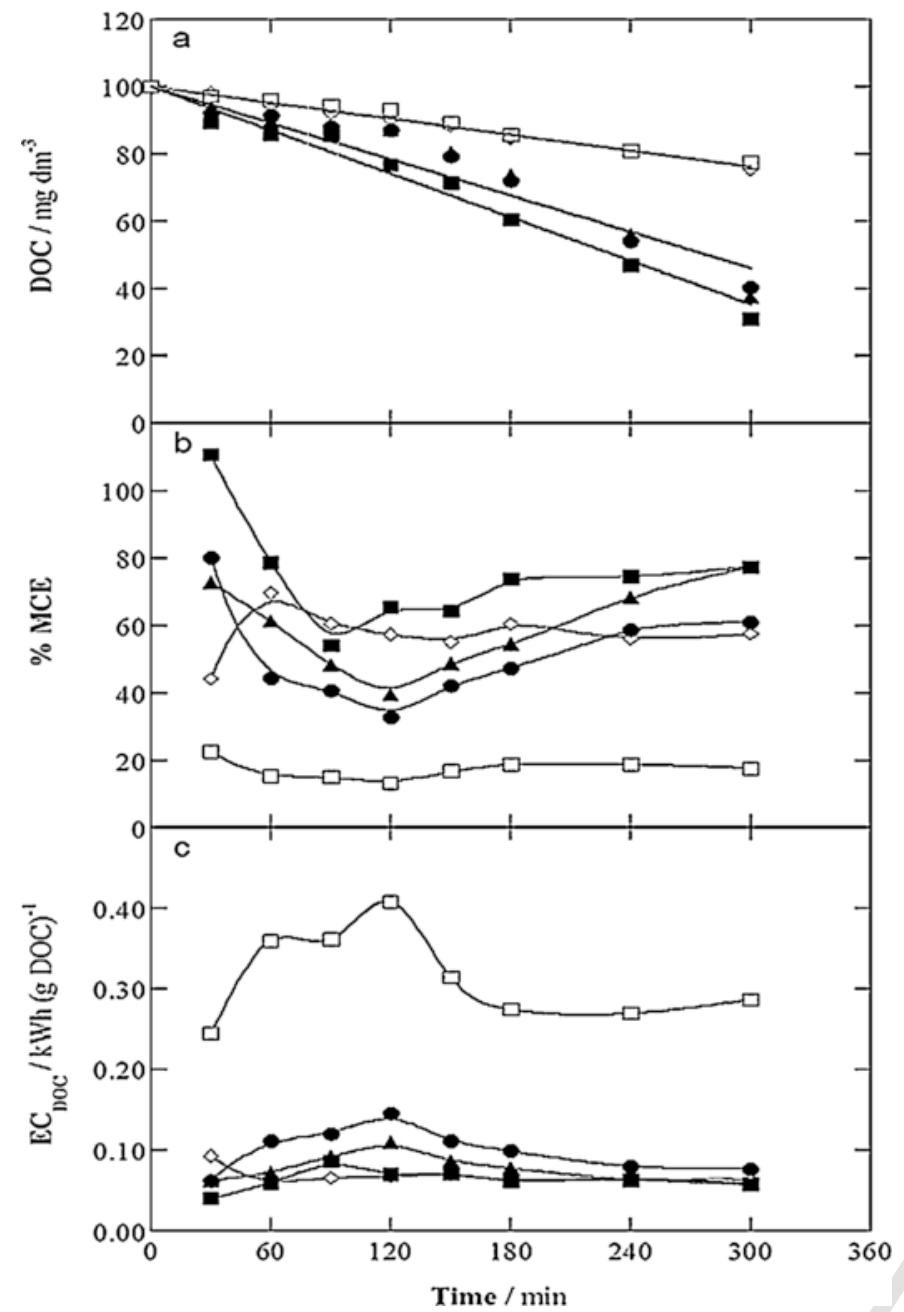

Fig. 5. Variation of (a) DOC, (b) mineralization current efficiency and (c) specific energy consumption per gram of DOC with electrolysis time for the SPEF treatments at cathodic current densities of: $(\diamond) 0.075 \mathrm{~mA} \mathrm{~cm}^{-2},(\boldsymbol{\Delta}) 0.14 \mathrm{~mA} \mathrm{~cm}^{-2}$, (घ) $0.16 \mathrm{~mA} \mathrm{~cm}^{-2},(\bullet) 0.18 \mathrm{~mA} \mathrm{~cm}^{-2}$ and (ㅁ) $0.23 \mathrm{~mA} \mathrm{~cm}^{-2}$. Treated solution: $100 \mathrm{mg} \mathrm{dm}^{-3}$ DOC of ERY with $0.050 \mathrm{~mol} \mathrm{dm}^{-3} \mathrm{Na}_{2} \mathrm{SO}_{4}$ and $0.50 \mathrm{mmol} \mathrm{dm}{ }^{-3} \mathrm{Fe}^{2+}$ at $\mathrm{pH}=3.0$. Volumetric inflow rate $Q=3.0 \mathrm{dm}^{3} \mathrm{~min}^{-1}$. Solid lines (-) of Fig. 5a correspond to the theoretical data obtained from the parametric model considering $C_{0}{ }^{\circ}=$ DOC. Only three simulated curves are represented because quite similar calculations were found for 0.075 and $0.23 \mathrm{~mA} \mathrm{~cm}^{-2}$, as well for 0.14 and $0.18 \mathrm{~mA} \mathrm{~cm}^{-2}$.

$j=0.16 \mathrm{~mA} \mathrm{~cm}^{-2}$. However, similar $\mathrm{MCE}$ and $\mathrm{EC}_{\mathrm{DOC}}$ values were found for a lower $j=0.14 \mathrm{~mA} \mathrm{~cm}^{-2}$, although reaching a smaller DOC decay of $62 \%$ (see Fig. 5a). This suggests a larger consumption of - $\mathrm{OH}$ at increasing $\mathrm{H}_{2} \mathrm{O}_{2}$ concentration by parasitic reactions (15) and (16) [22-24]:

$$
\begin{aligned}
& \bullet \mathrm{OH} \rightarrow \mathrm{H}_{2} \mathrm{O}_{2} \\
& \mathrm{H}_{2} \mathrm{O}_{2}+\cdot \cdot \mathrm{OH} \rightarrow \mathrm{HO}_{2} \cdot+\mathrm{H}_{2} \mathrm{O}
\end{aligned}
$$

It is worth mentioning that in all the above trials the solution $\mathrm{pH}$ decayed slightly up to a final value near $2.7-2.8$, probably by the production of acidic products like short-linear aliphatic carboxyl acids [22-25]. The protons generated upon mineralization of ERY as shown in reaction (11) may also contribute to such slight $\mathrm{pH}$ decay.
Fig. 6a depicts the DOC-time plots obtained for a $0.225 \mathrm{mmol} \mathrm{dm}{ }^{-3}$ ERY solution with $0.50 \mathrm{mmol} \mathrm{dm}^{-3} \mathrm{Fe}^{2+}$ at $\mathrm{pH} 3.0$ and $j=0.16 \mathrm{~mA} \mathrm{~cm}^{-2}$ at $Q$ values ranging between 2.3 and $3.7 \mathrm{dm}^{3} \mathrm{~min}^{-1}$. A large improvement of the mineralization rate could be observed when $Q$ rose from 2.3 and $3.0 \mathrm{dm}^{3} \mathrm{~min}^{-1}$, which can be associated with an enhancement of mass transport of oxygen and protons to yield $\mathrm{H}_{2} \mathrm{O}_{2}$ by reaction (1). At a higher $Q$ of $3.7 \mathrm{dm}^{3} \mathrm{~min}^{-1}$, however, this trend was inverted, probably due to the concomitant decrease in the residence time inside the electrochemical reactor that causes a drop of $\mathrm{H}_{2} \mathrm{O}_{2}$ production and, consequently, of the SFEP process efficiency. This latter assumption considers that in the CPC photoreactor the mineralization process mainly occurs by the action of $\bullet \mathrm{OH}$ formed in the bulk, being strongly determined by the amount $\mathrm{H}_{2} \mathrm{O}_{2}$ produced in the FM01-LC reactor. The final MCE at 2.3, 3.0 and $3.7 \mathrm{dm}^{3} \mathrm{~min}^{-1}$ were $58 \%, 75 \%$ and $71 \%$, respectively, with $\mathrm{EC}_{\mathrm{DOC}}$ values of $0.077,0.059$ and $0.062 \mathrm{kWh}(\mathrm{g} \mathrm{DOC})^{-1}$, and $\rho_{\mathrm{ST}}$ values of $0.0002,0.00035$ and $0.0004 \mathrm{~g} \mathrm{dm}^{-3} \mathrm{~s}^{-1}$. It is important to mention that, in Fig. 6a, the best electrolysis in terms of DOC depletion and MCE was obtained at $3.0 \mathrm{dm}^{3} \mathrm{~min}^{-1}$.

The above assays revealed that the influence of hydrodynamics on DOC decay is not so significant, although it is true that the best linear DOC versus time trend was obtained at $Q$ of $3.0 \mathrm{dm}^{3} \mathrm{~min}^{-1}$ for the SPEF process in the solar flow plant. This value, along with the optimum ones of $0.50 \mathrm{mmol} \mathrm{dm}{ }^{-3} \mathrm{Fe}^{2+}$ and $j=0.16 \mathrm{~mA} \mathrm{~cm}^{-2}$, were used

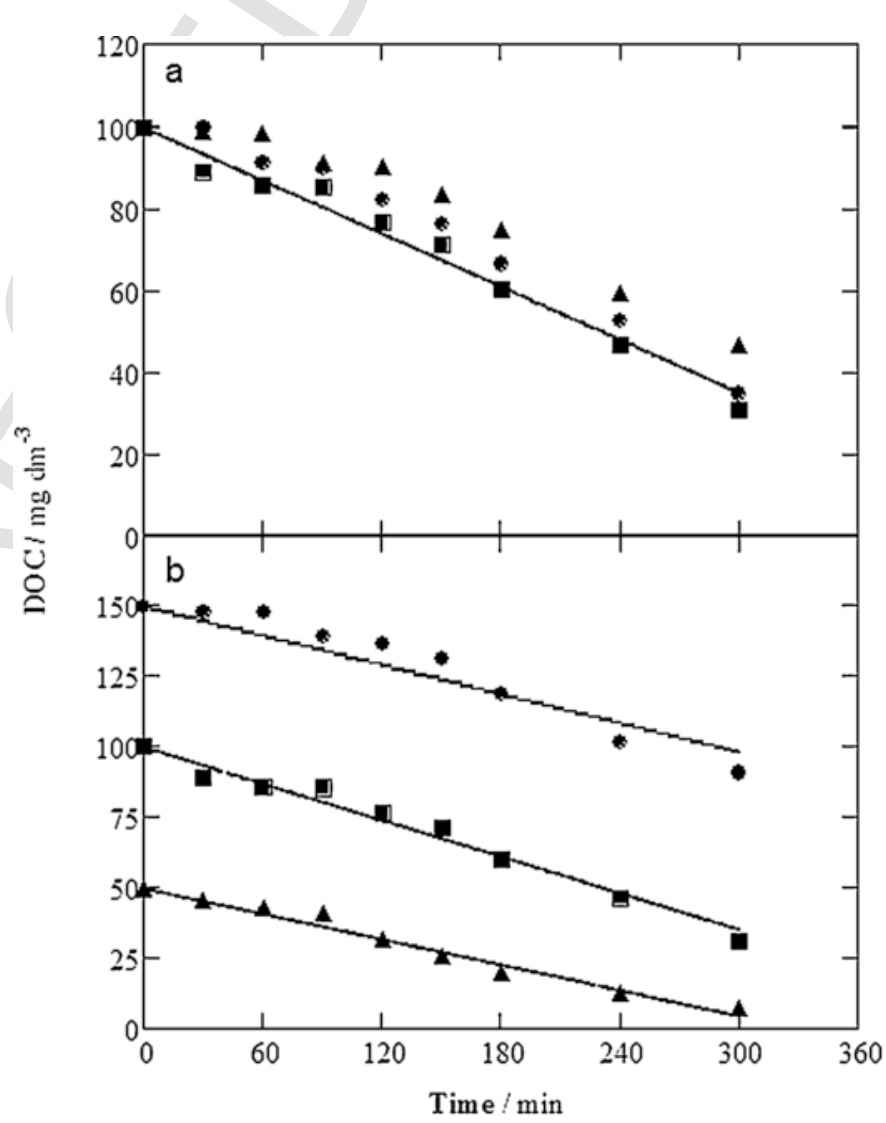

Fig. 6. (a) DOC decay vs electrolysis time for the SPEF treatment of a

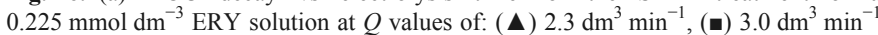
and $(\bullet) 3.7 \mathrm{dm}^{3} \mathrm{~min}^{-1}$. Electrolyte: $0.050 \mathrm{~mol} \mathrm{dm}^{-3} \mathrm{Na}_{2} \mathrm{SO}_{4}$ with $0.50 \mathrm{mmol} \mathrm{dm}{ }^{-3} \mathrm{Fe}^{2+}$ at $\mathrm{pH}=3.0$. The cathodic current density was $0.16 \mathrm{~mA} \mathrm{~cm}^{-2}$. (b) $\mathrm{DOC}$ removal with electrolysis time for the SPEF experiments with initial DOC of: (A) $50 \mathrm{mg} \mathrm{dm}^{-3}$, (ם) $100 \mathrm{mg} \mathrm{dm}^{-3}$ and $(\bullet) 150 \mathrm{mg} \mathrm{dm}^{-3}$, at $Q=3.0 \mathrm{dm}^{3} \mathrm{~min}^{-1}$. Solid lines $(-)$ are the theoretical data determined from the parametric model taking $C_{0}=$ DOC. The curves at 2.3 and $3.7 \mathrm{dm}^{3} \mathrm{~min}^{-1}$ were not modeled because of the unclear linear trend. 
to assess the effect of the antibiotic concentration between 0.112 and $0.337 \mathrm{mmol} \mathrm{dm}^{-3}$ on its mineralization trends. As shows Fig. 6b, a lower mineralization was attained at growing ERY concentrations, as expected by the smaller removal of pollutants at higher organic load by similar constant quantities of oxidants produced under the same conditions. Although DOC was reduced by $85 \%, 69 \%$ and $40 \%$ at raising antibiotic contents of $0.112,0.225$ and $0.337 \mathrm{mmol} \mathrm{dm}^{-3}$, a larger quantity of DOC was destroyed when going from 0.112 and $0.225 \mathrm{mmol} \mathrm{dm}^{-3}$, which agrees with the obtained values of $\rho_{\mathrm{ST}}$ (Table 4). This was reflected in the corresponding enhancement of MCE from $46 \%$ to $75 \%$ and decrease of $\mathrm{EC}_{\mathrm{DOC}}$ from 0.093 to 0.059 $\mathrm{kWh}\left(\mathrm{g} \mathrm{DOC}^{-1}\right)$. In contrast, the MCE value of the $0.337 \mathrm{mmol} \mathrm{dm}^{-3}$ solution decayed to $65 \%$ with an $\mathrm{EC}_{\mathrm{DOC}}=0.071 \mathrm{kWh}(\mathrm{g} \mathrm{DOC})^{-1}$. These results indicate that the reaction rates of parasitic reactions (10), (15) and (16) were minimal at $0.225 \mathrm{mmol} \mathrm{dm}^{-3}$. Consequently, the experimental characterization of the SPEF treatment of ERY solutions in $0.050 \mathrm{~mol} \mathrm{dm}^{-3} \mathrm{Na}_{2} \mathrm{SO}_{4}$ at $\mathrm{pH} 3.0$ revealed optimum conditions for $0.225 \mathrm{mmol} \mathrm{dm}^{-3}$ antibiotic concentration with $0.50 \mathrm{mmol} \mathrm{dm}^{-3} \mathrm{Fe}^{2+}$ at $j=0.16 \mathrm{~mA} \mathrm{~cm}^{-2}$ and $Q=3.0 \mathrm{dm}^{3} \mathrm{~min}^{-1}$, giving rise to $69 \%$ mineralization with $\mathrm{MCE}$ of $75 \%, \mathrm{EC}_{\mathrm{DOC}}$ of $0.059 \mathrm{kWh}(\mathrm{g} \mathrm{DOC})^{-1}$ and $\rho_{\mathrm{ST}}$ of $0.00035 \mathrm{~g} \mathrm{dm}^{-3} \mathrm{~s}^{-1}$ at $300 \mathrm{~min}$.

\subsection{Comparison of the parametric model with experimental results}

Figs. 4a, 5a, 6a and b shows the simulated DOC-time plots as solid lines determined from the proposed parametric model. Dispersion modules for both reactors, which were experimentally obtained by RTD analysis [60], are shown in Table 3. Apparent pseudo-zero-order kinetic constants determined according to the model are summarized in Table 4 including the linear regression coefficient, $R^{2}$, between theoretical and experimental data. Fig. 4a shows close agreement between theoretical and experimental results operating under potentiostatic conditions with an $E_{\text {cat }}=-0.35 \mathrm{~V}$ vs SHE to produce $\mathrm{H}_{2} \mathrm{O}_{2}$ in the FM01-LC, avoiding the parasitic HER [53]. When the SPEF process operated under galvanostatic conditions (Figs. 5a, 6a and b) the model did not show a perfect agreement. In Fig. 5a, which assesses the effect of $j$, significant deviations can be observed for 0.14 and $0.18 \mathrm{~mA} \mathrm{~cm}^{-2}$ between 90 and $150 \mathrm{~min}$, owing to the variations of $E_{\mathrm{cat}}$ giving rise to similar experimental data. In Fig. 6a, which shows the effect of hydrodynamics on DOC decay, the simulation became worse when the SPEF process operated at 2.3 and $3.7 \mathrm{dm}^{3} \mathrm{~min}^{-1}$, with a very similar experimental trend to that obtained at 0.14 and $0.18 \mathrm{~mA} \mathrm{~cm}^{-2}$ (Fig. 5a). This behavior indicates that under such hydrodynamic conditions the parasitic HER takes place at a large extent, inhibiting the degradation of ERY. However, at $3.0 \mathrm{dm}^{3} \mathrm{~min}^{-1}$, the model presents close agreement with the experimental DOC-time plot (solid line). Also, good agreement was obtained between the model and experiments during the effect of antibiotic content, as can be seen in Fig. 6 b. From the analysis of the above figures, one can conclude that the proposed parametric model, in terms of mass balance equations of ERY, could fit well when the $\mathrm{H}_{2} \mathrm{O}_{2}$ production is favored and parasitic HER is minimized, always considering a constant sunlight radiation. Worthy mentioning that the linear regression coefficients were comprised between $0.92 \leq R^{2} \leq 0.99$; in our opinion these values of $R^{2}$ are acceptable in such SPEF process because the stochastic experimental point deviations, from the linear DOC versus time plots depicted in Figs. $4 \mathrm{a}$, $5 \mathrm{a}, 6 \mathrm{a}$ and $\mathrm{b}$, are attributed to the sunlight radiation variation (during the $8 \mathrm{~h}$ of the experiments). A more robust parametric model that includes the effect of $\mathrm{H}_{2} \mathrm{O}_{2}$ concentration as a function of sunlight radiation and $j$ and should be taken into account for future research at large scale.
It is important to remark that the parametric model developed here was designed to understand and correlate the experimental DOC decay with time (including formed by-products and intermediates). In other words, this model allowed determining the global apparent reaction term of the DOC in the solution, without the contribution of the non-ideal flow deviations in the FM01-LC and CPC reactors. In this global apparent reaction term, ${ }^{\bullet} \mathrm{OH}$ is presupposed as the most powerful oxidant, although slower reactions with other weaker oxidizing species like $\mathrm{H}_{2} \mathrm{O}_{2}$ and $\mathrm{HO}_{2}{ }^{*}$ is feasible. This first approach should also serve as a starting point the scale-up of the SPEF process, which will be performed in near future.

\subsection{Identification and time course of intermediates and released inorganic ions}

Table 5 summarizes the characteristics of six intermediates detected by GC-MS during short electrolysis times of the SPEF treatment of a $0.225 \mathrm{mmol} \mathrm{dm}^{-3}$ ERY solution with $0.05 \mathrm{~mol} \mathrm{dm}^{-3}$ $\mathrm{Na}_{2} \mathrm{SO}_{4}$ and $0.50 \mathrm{mmol} \mathrm{dm}{ }^{-3} \mathrm{Fe}^{2+}$ at $\mathrm{pH} 3.0, j=0.16 \mathrm{~mA} \mathrm{~cm}^{-2}$ and $Q=3.0 \mathrm{dm}^{3} \mathrm{~min}^{-1}$. The degradation of ERY (1) yields four heterocyclic by-products (compounds $\mathbf{2 , 3}, \mathbf{4}$ and $\mathbf{6}$ ), the aromatic methyl ester derivative $\mathbf{5}$ and the tertiary aliphatic amine $\mathbf{7}$. All these small compounds are formed from the cleavage of the multiple $\mathrm{C}-\mathrm{C}$ bonds of the complex structure of the ERY molecule under the action of ${ }^{\bullet} \mathrm{OH}$, followed by internal cyclization to yield some of the heterocyclic and aromatic structures. These by-products have not been detected in a recent study on an enzymatic degradation of ERY [64].

Subsequent degradation of compounds 2-7 is expected to give a mixture of final short-chain aliphatic carboxylic acids [22-25]. This fact was corroborated by ion-exclusion HPLC analysis of the above treated $0.225 \mathrm{mmol} \mathrm{dm}^{-3}$ ERY solution, which revealed the formation of maleic, fumaric, oxamic, oxalic and formic acids. The two former acids are oxidized to oxalic and formic [37-43], whereas oxamic acid proceeds from the destruction of $N$-intermediates like the aliphatic amine shown in Table 5. Oxamic, oxalic and formic acids are final by-products that are directly mineralized to $\mathrm{CO}_{2}$. Under the present experimental conditions, all detected acids form $\mathrm{Fe}$ (III) complexes to large extent $[22,23,44]$.

Only traces of maleic, fumaric and oxamic acids $\left(<0.002 \mathrm{mmol} \mathrm{dm}^{-3}\right)$ were detected during the electrolysis. In contrast, formic and oxalic acids were largely accumulated in the solution. Fig. 7 a illustrates a maximum content of $0.415 \mathrm{mmol} \mathrm{dm}^{-3}$ for formic acid at $120 \mathrm{~min}$ of electrolysis, which was significantly reduced to a final value of $0.085 \mathrm{mmol} \mathrm{dm}^{-3}$. In the case of oxalic acid, it was accumulated to a smaller extent up to $0.144 \mathrm{mmol} \mathrm{dm}^{-3}$. This behavior can be accounted for by the efficient removal of $\mathrm{Fe}$ (III)-formate and $\mathrm{Fe}(\mathrm{III})$-oxalate complexes upon the action of UV light of the incident solar radiation over the CPC photoreactor via reaction (6) $[43,44]$. A mass balance of all these acids at $300 \mathrm{~min}$ indicated that they accounted for $4.5 \mathrm{mg} \mathrm{dm}^{-3}$ DOC out of the $31 \mathrm{mg} \mathrm{dm}^{-3}$ contained in the final solution. This means that about $85 \%$ of its organic content is due to other unidentified by-products that are hardly removed by ${ }^{\bullet} \mathrm{OH}$ and solar radiation. Further research is needed to ensure that this unknown remaining of DOC is harmless to living beings. This should involve toxicological and $\mathrm{BOD}_{5}$ analysis, which were beyond of the scope of this paper.

The fate of the initial $\mathrm{N}$ atom of the $0.225 \mathrm{mmol} \mathrm{dm}^{-3} \mathrm{ERY}$ solution upon SPEF treatment was assessed. $\mathrm{NO}_{3}{ }^{-}$and $\mathrm{NH}_{4}{ }^{+}$were the unique inorganic ions detected, with preferential formation of the former ion, as proposed in reaction (11). Fig. 7b shows a progressive accumulation of $\mathrm{NO}_{3}{ }^{-}$up to $0.072 \mathrm{mmol} \mathrm{dm}{ }^{-3}$, as a result of the continuous mineralization of $\mathrm{N}$-intermediates. A final $\mathrm{NH}_{4}^{+}$concentration of $0.047 \mathrm{mmol} \mathrm{dm}{ }^{-3}$ was found. The sum of the $\mathrm{N}$ content of such inor- 
Table 5

Intermediates identified by GC-MS during the SPEF treatment of erythromycin (1) at pH 3.0 in the recirculation plant.

\begin{tabular}{|c|c|c|c|c|}
\hline Number & Chemical name & Molecular structure & $\begin{array}{l}t_{\mathrm{r}}^{\mathrm{a}} \\
(\min )\end{array}$ & Main fragmentation ions $(\mathrm{m} / \mathrm{z})$ \\
\hline 2 & 1-(2,4-Dimethyl-3-furyl)ethanone & & 13.3 & $138,12367,43$ \\
\hline 3 & 3-Hydroxy-2,6-dimethyl-4H-pyran-4-one & & 13.4 & $140,125111,97,85,69,43$ \\
\hline 4 & Dehydroacetic acid & & 17.7 & $168,153125,111,98,85,43$ \\
\hline 5 & 3,5-Dihydroxymethylacetic acid methyl ester & & 20.3 & $182,123,43$ \\
\hline 6 & 2-Furancarboxylic acid & & 20.5 & $112,95,39$ \\
\hline 7 & $N, N$-Dimethyl-1-ol-2-pentanamine & $\mathrm{H}_{2} \mathrm{C}$ & 22.0 & $131,87,72,56,44$ \\
\hline
\end{tabular}

a Retention time.

ganic ions represents a $53 \%$ of its initial value, suggesting that a significant quantity of refractory $N$-intermediates are accumulated in the final solution. Some volatile $N$-species may also be formed, although their contribution is probably of minor importance.

\section{Conclusions}

It has been shown that the ERY solutions in acidic sulfate medium can be mineralized by the powerful SPEF process using a $10 \mathrm{dm}^{3}$ solar flow plant with a FM01-LC reactor coupled to a solar CPC photoreactor. Under potentiostatic conditions at $E_{\text {cat }}=-0.35 \mathrm{~V}$ vs SHE, which ensured constant $\mathrm{H}_{2} \mathrm{O}_{2}$ production, a $0.225 \mathrm{mmol} \mathrm{dm}^{-3}$ antibiotic solution with optimum $0.50 \mathrm{mmol} \mathrm{dm}{ }^{-3} \mathrm{Fe}^{2+}$ content treated at $Q=3.0 \mathrm{dm}^{3} \mathrm{~min}^{-1}$ underwent $78 \%$ of mineralization with $84 \%$ of MCE, $0.059 \mathrm{kWh}(\mathrm{g} \text { DOC) })^{-1}$ of $\mathrm{EC}_{\mathrm{DOC}}$ and space-time yield of $0.00028 \mathrm{~g} \mathrm{dm}^{-3} \mathrm{~s}^{-1}$ at $300 \mathrm{~min}$. Under galvanostatic conditions, the optimal treatment of a $0.225 \mathrm{mmol} \mathrm{dm}{ }^{-3}$ ERY solution was achieved at $0.16 \mathrm{~mA} \mathrm{~cm}^{-2}$ and $3.0 \mathrm{dm}^{3} \mathrm{~min}^{-1}$, finally reaching $69 \%$ of mineralization, $75 \%$ of current efficiency, $0.059 \mathrm{kWh}(\mathrm{g} \mathrm{DOC})^{-1}$ of $\mathrm{EC}_{\mathrm{DOC}}$ and space-time yield of $0.00035 \mathrm{~g} \mathrm{dm}^{-3} \mathrm{~s}^{-1}$. Four heterocycles and one aromatic by-product, along with a tertiary aliphatic amine, were formed by $\bullet \mathrm{OH}$ attack, thereby yielding five final carboxylic acids with predominance of formic and oxalic. The initial $\mathrm{N}$ atoms were pre-eminently mineralized to $\mathrm{NO}_{3}{ }^{-}$ion, although a significant proportion of unidentified $N$-intermediates were also formed. The parametric model allowed determining the global apparent reaction term of the total DOC decay by SPEF, assuming ${ }^{\bullet} \mathrm{OH}$ as the most powerful oxidant and disregarding the contribution of non-ideal flow deviations in both reactors. The model was validated under potentiostatic conditions, whereas it worked adequately at constant current when the $\mathrm{H}_{2} \mathrm{O}_{2}$ production was favored over the HER. However, a more robust model including the $\mathrm{H}_{2} \mathrm{O}_{2}$ concentration $v s j$ and sunlight radiation should be conceived in future research, as a first approach for the scale-up of the SPEF flow plant.

\section{Acknowledgments}

The authors would like to thank the following organizations for their financial support: CONACYT (Mexico) under Project 240522, 


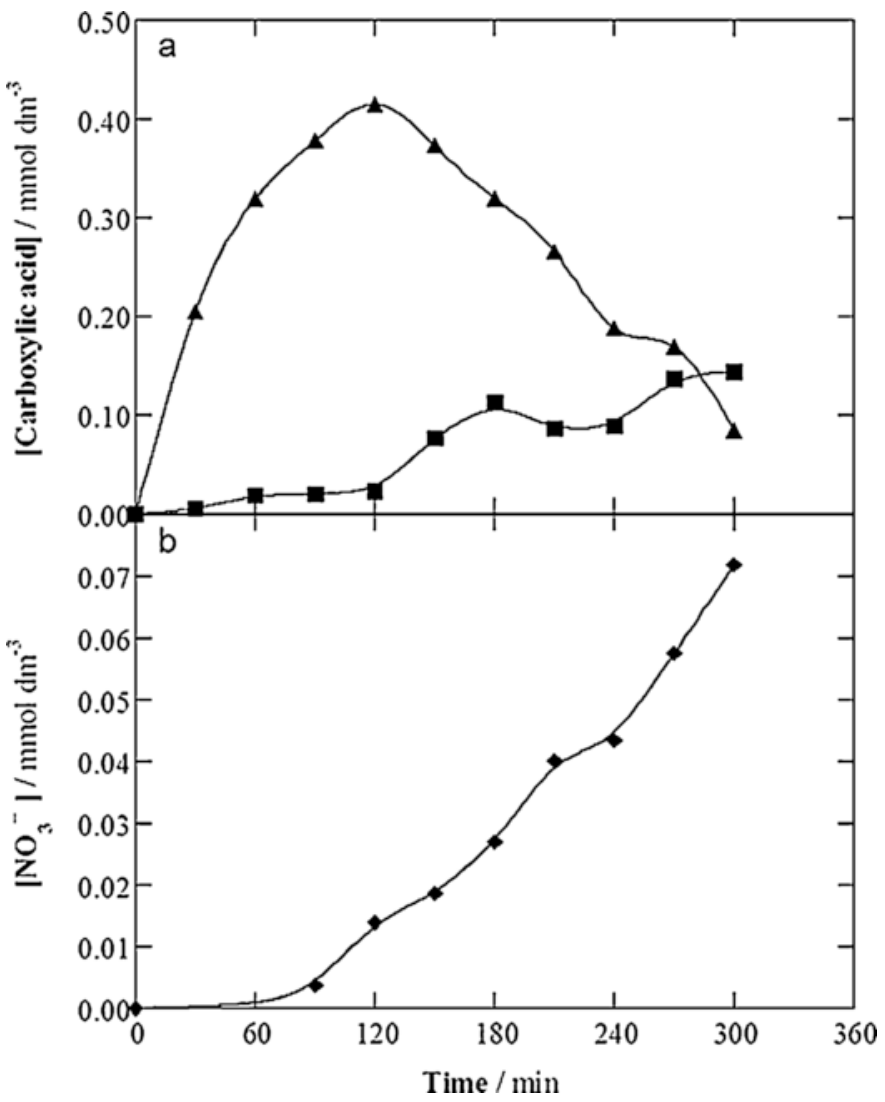

Fig. 7. (a) Evolution of the concentration of ( $\boldsymbol{\Delta})$ formic and ( $\boldsymbol{\square})$ oxalic acids detected during the SPEF degradation of a $0.225 \mathrm{mmol} \mathrm{dm}^{-3}$ ERY solution in $0.050 \mathrm{~mol} \mathrm{dm}^{-3}$ $\mathrm{Na}_{2} \mathrm{SO}_{4}$ with $0.50 \mathrm{mM} \mathrm{Fe}{ }^{2+}$ at $\mathrm{pH}=3.0, Q=3.0 \mathrm{dm}^{-3} \mathrm{~min}^{-1}$ and cathodic current density of $0.16 \mathrm{~mA} \mathrm{~cm}^{-2}$. (b) Time-course of released $\mathrm{NO}_{3}{ }^{-}$ion in the same trial.

\section{MINECO (Spain) and FEDER (EU) under Project CTQ2016-78616-R, and Universidad de Guanajuato under Project $869 / 2016$.}

\section{References}

[1] Z. Cetecioglu, B. Ince, O. Ince, D. Orhon, Acute effect of erythromycin on metabolic transformations of volatile fatty acid mixture under anaerobic conditions, Chemosphere 124 (2015) 129-135.

[2] S.C. Sweetman, The Complete Drug Reference, 34th ed., Pharmaceutical Press, London, UK, 2009.

[3] J.V. Pothuluri, M. Nawaz, C.E. Cerniglia, Environmental fate of antibiotics used in aquaculture, In: S.K. Sikdar, R.L. Irvine (Eds.), Bioremediation: Principles and Practice, vol. II, Biodegradation Technology Developments, Technomic Publishing Co., Lancaster-Basel, 1998, pp. 221-248.

[4] Y.-H. Kim, T.M. Heinze, R. Beger, J.V. Pothuluri, C.E. Cerniglia, A kinetic study on the degradation of erythromycin A in aqueous solution, Int. J. Pharm. 271 (2004) 63-76.

[5] S.K. Khetan, T.J. Collins, Human pharmaceuticals in the aquatic environment: challenge to green chemistry, Chem. Rev. 107 (2007) 2319-2364.

[6] I. Sirés, E. Brillas, Remediation of water pollution caused by pharmaceutical residues based on electrochemical separation and degradation technologies: A review, Environ. Int. 40 (2012) 212-229.

[7] M.O. Barbosa, N.F.F. Moreira, A.R. Ribeiro, M.F.R. Pereira, A.M.T. Silva, Occurrence and removal of organic micropollutants: An overview of the watch list of EU Decision 2015/495, Water Res. 94 (2016) 257-279.

[8] J.T. Wilson, C.J. Van Boxtel, Pharmacokinetics of erythromycin in man, Antibiot. Chemother. 25 (1978) 181-203.

[9] R.S. Griffith, R.H. Black, Erythromycin, Med. Clin. North Am. 54 (1970) 1199-1215.

[10] K. Kümmerer, Antibiotics in the aquatic environment - A review - Part I, Chemosphere 75 (2009) 417-434.
[11] S.R. Batchu, V.R. Panditi, K.E. O'Shea, P.R. Gardinali, Photodegradation of antibiotics under simulated solar radiation: Implications for their environmental fate, Sci. Total Environ. 470-471 (2014) 299-310.

[12] Y. Nakagawa, S. Itai, T. Yoshida, T. Nagai, Physicochemical properties and stability in the acidic solution of a new macrolide antibiotic clarithromycin, in comparison with erythromycin, Chem. Pharm. Bull. 40 (1992) 725-728.

[13] A.C. Johnson, V. Keller, E. Dumont, J.P. Sumpter, Assessing the concentrations and risks of toxicity from the antibiotics ciprofloxacin sulfamethoxazole, trimethoprim and erythromycin in European rivers, Sci. Total Environ. 511 (2015) 747-755.

[14] D.W. Kolpin, E.T. Furlong, M.T. Meyer, E.M. Thurman, S.D. Zaugg, L.B. Barber, H.T. Buxton, Pharmaceuticals hormones, and other organic wastewater contaminants in U.S. streams, 1999-2000: A national reconnaissance, Environ. Sci. Technol. 36 (2002) 1202-1211.

[15] J. Wan, P. Guo, X. Peng, K. Wen, Effect of erythromycin exposure on the growth, antioxidant system and photosynthesis of Microcystis flos-aquae, J. Hazard. Mater. 283 (2015) 778-786.

[16] E.M. Smith, F.I. Iftikar, S. Higgins, A. Irshad, R. Jandoc, M. Lee, J.Y. Wilson, In vitro inhibition of cytochrome P450-mediated reactions by gemfibrozil erythromycin, ciprofloxacin and fluoxetine in fish liver microsomes, Aquat. Toxicol. 109 (2012) 259-266.

[17] J. Liu, G. Lu, J. Ding, Z. Zhang, Y. Wang, Tissue distribution bioconcentration, metabolism, and effects of erythromycin in crucian carp (Carassius auratus), Sci. Total Environ. 490 (2014) 914-920.

[18] R.J. Carman, M.A. Simon, H.E. Petzold 3rd, R.F. Wimmer, M.R. Batra, A.H. Fernández, M.A. Miller, M. Bartholomew, Antibiotics in the human food chain: Establishing no effect levels of tetracycline, neomycin, and erythromycin using a chemostat model of the human colonic microflora, Regul. Toxicol. Pharm. 43 (2005) 168-180.

[19] A.Y.-C. Lin, C.-F. Lin, J.-M. Chiou, P.K.A. Hong, $\mathrm{O}_{3}$ and $\mathrm{O}_{3} / \mathrm{H}_{2} \mathrm{O}_{2}$ treatment of sulfonamide and macrolide antibiotics in wastewater, J. Hazard. Mater. 171 (2009) 452-458.

[20] H.M. Menapace, N. Diaz, S. Weiss, Electrochemical treatment of pharmaceutical wastewater by combining anodic oxidation with ozonation, J. Environ. Sci. Health Part A 43 (2008) 961-968.

[21] S. Aydin, B. Ince, Z. Cetecioglu, O. Arikan, E.G. Ozbayram, A. Shahi, O. Ince, Combined effect of erythromycin, tetracycline and sulfamethoxazole on performance of anaerobic sequencing batch reactors, Bioresour. Technol. 186 (2015) 207-214.

[22] I. Sirés, E. Brillas, M.A. Oturan, M.A. Rodrigo, M. Panizza, Electrochemical advanced oxidation processes: today and tomorrow. A review, Environ. Sci. Pollut. Res. 21 (2014) 8336-8367.

[23] C.A. Martínez-Huitle, M.A. Rodrigo, I. Sirés, O. Scialdone, Single and coupled electrochemical processes and reactors for the abatement of organic water pollutants: A critical review, Chem. Rev. 115 (2015) 13362-13407.

[24] E. Brillas, C.A. Martínez-Huitle, Decontamination of wastewaters containing synthetic organic dyes by electrochemical methods. An updated review, Appl. Catal. B: Environ. 166-167 (2015) 603-643.

[25] F.C. Moreira, R.A.R. Boaventura, E. Brillas, V.J.P. Vilar, Electrochemical advanced oxidation processes: A review on their application to synthetic and real wastewaters, Appl. Catal. B: Environ. 202 (2017) 217-261.

[26] I. Michael-Kordatou, M. Iacovou, Z. Frontistis, E. Hapeshi, D.D. Dionysiou, D. Fatta-Kassinos, Erythromycin oxidation and ERY-resistant Escherichia coli inactivation in urban wastewater by sulfate radical-based oxidation process under UV-C irradiation, Water Res. 85 (2015) 346-358.

[27] P. Karaolia, I. Michael-Kordatou, E. Hapeshi, J. Alexander, T. Schwartz, D. Fatta-Kassinos, Investigation of the potential of a Membrane BioReactor followed by solar Fenton oxidation to remove antibiotic-related microcontaminants, Chem. Eng. J. (2016) http://dx.doi.org/10.1016/j.cej.2016.04.113.

[28] N. Chen, L.J. Huang, N. Liu, Y. Liu, S.F. Wang, Analysis of the effect of erythromycin wastewater degradation by Fenton method, Asian J. Chem. 25 (2013) 7208-7210.

[29] T. Mackul'ak, K. Nagyová, M. Faberová, R. Grabic, O. Koba, M. Gál, L. Birošová, Utilization of Fenton-like reaction for antibiotics and resistant bacteria elimination in different parts of WWTP, Environ. Toxicol. Pharm. 40 (2015) 492-497.

[30] N.P. Xekoukoulotakis, N. Xinidis, M. Chroni, D. Mantzavinos, D. Venieri, E. Hapeshi, D. Fatta-Kassinos, UV-A/TiO 2 photocatalytic decomposition of erythromycin in water: Factors affecting mineralization and antibiotic activity, Catal. Today 151 (2010) 29-33.

[31] A. Wang, J. Qu, H. Liu, J. Ru, Mineralization of an azo dye Acid Red 14 by photoelectro-Fenton process using an activated carbon fiber cathode, Appl. Catal. B: Environ. 84 (2008) 393-399.

[32] N. Daneshvar, S. Aber, V. Vatanpour, M.H. Rasoulifard, Electro-Fenton treatment of dye solution containing Orange II: Influence of operational parameters, J. Electroanal. Chem. 615 (2008) 165-174.

[33] N. Oturan, E. Brillas, M.A. Oturan, Unprecedented total mineralization of atrazine and cyanuric acid by anodic oxidation and electro-Fenton with a boron-doped diamond anode, Environ. Chem. Lett. 10 (2012) 165-170. 
[34] A. Dirany, I. Sirés, N. Oturan, A. Özcan, M.A. Oturan, Electrochemical treatment of the antibiotic sulfachloropyridazine: kinetics, reaction pathways, and toxicity evolution, Environ. Sci. Technol. 46 (2012) 4074-4082.

[35] A. El-Ghenymy, R.M. Rodríguez, E. Brillas, N. Oturan, M.A. Oturan, Electro-Fenton degradation of the antibiotic sulfanilamide with Pt/carbon-felt and $\mathrm{BDD} /$ carbon-felt cells. Kinetics reaction intermediates, and toxicity assessment, Environ. Sci. Pollut. Res. 21 (2014) 8368-8378.

[36] F. Sopaj, M.A. Rodrigo, N. Oturan, F.I. Podvorica, J. Pinson, M.A. Oturan, Influence of the anode materials on the electrochemical oxidation efficiency. Application to oxidative degradation of the pharmaceutical amoxicillin, Chem. Eng. J. 262 (2015) 286-294.

[37] X. Florenza, A.M.S. Solano, F. Centellas, C.A. Martínez-Huitle, E. Brillas, S. Garcia-Segura, Degradation of the azo dye Acid Red 1 by anodic oxidation and indirect electrochemical processes based on Fenton's reaction chemistry. Relationship between decolorization, mineralization and products, Electrochim. Acta 142 (2014) 276-288.

[38] S. Garcia-Segura, E.B. Cavalcanti, E. Brillas, Mineralization of the antibiotic chloramphenicol by solar photoelectro-Fenton: From stirred tank reactor to solar pre-pilot plant, Appl. Catal. B: Environ. 144 (2014) 588-598.

[39] A. Thiam, I. Sirés, E. Brillas, Treatment of a mixture of food color additives (E122, E124 and E129) in different water matrices by UVA and solar photoelectro-Fenton, Water Res. 81 (2015) 178-187.

[40] A. Thiam, I. Sirés, F. Centellas, P.L. Cabot, E. Brillas, Decolorization and mineralization of Allura Red AC azo dye by solar photoelectro-Fenton: Identification of intermediates, Chemosphere 136 (2015) 1-8.

[41] H. Olvera-Vargas, N. Oturan, M.A. Oturan, E. Brillas, Electro-Fenton and solar photoelectro-Fenton treatments of the pharmaceutical ranitidine in pre-pilot flow plant scale, Sep. Purif. Technol. 146 (2015) 127-135.

[42] T. Pérez, S. Garcia-Segura, A. El-Ghenymy, J.L. Nava, E. Brillas, Solar photoelectro-Fenton degradation of the antibiotic metronidazole using a flow plant with a Pt/air-diffusion cell and a CPC photoreactor, Electrochim. Acta 165 (2015) 173-181.

[43] S. Garcia-Segura, E. Brillas, Advances in solar photoelectro-Fenton: Decolorization and mineralization of the Direct Yellow 4 diazo dye using an autonomous solar pre-pilot plant, Electrochim. Acta 140 (2014) 384-395.

[44] E. Brillas, A review on the degradation of organic pollutants in waters by UV photoelectro-Fenton and solar photoelectro-Fenton, J. Braz. Chem. Soc. 25 (2014) 393-417.

[45] F.F. Rivera, C. Ponce de León, F.C. Walsh, J.L. Nava, The reaction environment in a filter-press laboratory reactor: the FM01-LC flow cell, Electrochim. Acta 161 (2015) 436-452.

[46] T. Pérez, C. Ponce de León, F.C. Walsh, J.L. Nava, Simulation of current distribution along a planar electrode under turbulent flow conditions in a laboratory filter-press flow cell, Electrochim. Acta 154 (2015) 352-360.

[47] T. Pérez, M.I. León, J.L. Nava, Numerical simulation of current distribution along the boron-doped diamond anode of a filter-press-type FM01-LC reactor during the oxidation of water, J. Electroanal. Chem. 707 (2013) 1-6.

[48] J. Colina-Marquez, F. Machuca-Martinez, G. Li Puma, Photocatalytic mineralization of commercial herbicides in a pilot-scale solar CPC reactor: photoreacto modeling and reaction kinetics constants independent of radiation field, Environ. Sci. Technol. 43 (2009) 8953-8960.
[49] S.J. Royaee, M. Sohrabi, Comprehensive study on wastewater treatment using photo-impinging streams reactor: residence time distribution and reactor modeling, Ind. Eng. Chem. Res. 51 (2012) 4152-4160.

[50] B.A. Wols, D.J.H. Harmsen, J. Wanders-Dijk, E.F. Beerendonk, C.H.M. Hofman-Caris, Degradation of pharmaceuticals in UV (LP) $/ \mathrm{H}_{2} \mathrm{O}_{2}$ reactors simulated by means of kinetic modeling and computational fluid dynamics (CFD), Water Res. 75 (2015) 11-24.

[51] M.J. Sampaio, C.G. Silva, A.M.T. Silva, J.L. Faria, Kinetic modelling for the photocatalytic degradation of phenol by using $\mathrm{TiO}_{2}$-coated glass raschig rings under simulated solar light, J. Chem. Technol. Biotechnol. 91 (2016) 346-352.

[52] F.F. Rivera, C. Ponce de León, J.L. Nava, F.C. Walsh, The filter-press FM01-LC laboratory flow reactor and its applications, Electrochim. Acta 163 (2015) 338-354.

[53] G. Coria, T. Pérez, I. Sirés, J.L. Nava, Mass transport studies during dissolved oxygen reduction to hydrogen peroxide in a filter-press electrolyzer using graphite felt, reticulated vitreous carbon and boron-doped diamond as cathodes, J. Electroanal. Chem. 757 (2015) 225-229.

[54] R. Oommen, S. Jayaraman, Development and performance analysis of compound parabolic solar concentrators with reduced gap losses - oversized reflector, Energy Conv. Manage. 42 (2001) 1379-1399.

[55] C. Salame, M. Aillerie, G. Khoury, O. Benhabiles, N. Chekir, W. Taane, Terragreen 2012: Clean energy solutions for sustainable environment (CESSE) determining of the residence time distribution in CPC reactor type, Energy Procedia 18 (2012) 368-376

[56] A. Rabl, N.B. Goodman, R. Winston, Practical design considerations for CPC solar collectors, Solar Energy 22 (1979) 373-381.

[57] M. Cruz-Díaz, F.F. Rivera, E.P. Rivero, I. González, The FM01-LC reactor modeling using axial dispersion model with a reaction term coupled with a continuous stirred tank (CST), Electrochim. Acta 63 (2012) 47-54.

[58] M.I. León, Z.G. Aguilar, J.L. Nava, Electrochemical combustion of indigo at ternary oxide coated titanium anodes, J. Electrochem. Sci. Eng. 4 (2014) $247-258$.

[59] G. Coria, I. Sirés, E. Brillas, J.L. Nava, Influence of the anode material on the degradation of naproxen by Fenton-based electrochemical processes, Chem. Eng. J. 304 (2016) 817-825.

[60] T. Pérez, PhD. Thesis: Design and Characterization of the Solar Photo-electroFenton Process to Degrade Pharmaceuticals in Synthetic Wastewater, Geomatics and Hydraulic Engineering, University of Guanajuato, 2015.

[61] O. Levenspiel, Chemical Reaction Engineering, 3rd ed., John Wiley \& Sons, New York, 1999.

[62] F.J. Welcher (Ed.), Standard Methods of Chemical Analysis, vol. 2, R.E. Krieger Publishers, Huntington, New York, 1975. Part B, p. 1827.

[63] F.C. Walsh, A First Course in Electrochemical Engineering, 1st ed., The Electrochemical Consultancy, England, 1993.

[64] M. Llorca, S. Rodríguez-Mozaz, O. Couillerot, K. Panigoni, J. de Gunzburg, S. Bayer, R. Czaja, D. Barceló, Identification of new transformation products during enzymatic treatment of tetracycline and erythromycin antibiotics at laboratory scale by an on-line turbulent flow liquid-chromatography coupled to a high resolution mass spectrometer LTQ-Orbitrap, Chemosphere 119 (2015) 90-98. 